\author{
Universidade de Brasília \\ Instituto de Ciências Humanas \\ Departamento de Serviço Social
}

\title{
A EDUCAÇÃO EM DIREITOS HUMANOS NO PROJETO POLÍTICO - PEDAGÓGICO DA ESCOLA CLASSE 304 NORTE DE BRASÍLIA
}

\section{MARIANA BARROS RODRIGUES}

Monografia apresentada como requisito para a conclusão do curso de Bacharel em Serviço Social da Universidade de Brasília - UnB.

Orientadora: Prof. Dra. Nair Heloisa Bicalho de Sousa

BRASÍLIA 
Agradeço a Deus, por abençoar meus caminhos. Aos meus queridos pais, Rose e Bené, pelo amor e apoio incondicional em todos os momentos; ao meu amor, Dani, pelo companheirismo e às minhas amigas, Kaka, Bibi e Celina, por eles estarem sempre ao meu lado, pela amizade, paciência e ajuda; à professora Nair pelos ensinamentos e pela convivência; a todos os meus familiares, amigos e pessoas que de alguma forma colaboraram com a minha formação profissional e crescimento pessoal. 
"Ninguém caminha sem aprender a caminhar, sem aprender a fazer o caminho caminhando, refazendo e retocando o sonho pelo qual se pôs a caminhar".

Paulo Freire 


\section{Resumo}

O presente trabalho pretende investigar o projeto político-pedagógico da Escola Classe 304 Norte de Brasília, levando em consideração sua importância para a formação dos alunos na área de educação em direitos humanos.O estudo definiu como objetivos específicos pesquisar os elementos do projeto político pedagógico: a finalidade da escola, a estrutura organizacional, o currículo, o tempo escolar, o processo de decisão, as relações de trabalho dos professores e o processo de avaliação da escola.

Levando em consideração que educar não significa receber passivamente os conteúdos, mas, um processo coletivo que permite aos alunos se tornarem pessoas conscientes e cidadãos críticos capazes de problematizar a realidade.Nesse sentido, é essencial que a escola tenha um projeto político-pedagógico como um instrumento de trabalho capaz de assegurar o direito humano à educação com qualidade e comprometido com a questão dos direitos humanos, tendo em vista a construção de uma sociedade verdadeiramente democrática.

Os dados coletados na investigação demonstram que a Escola Classe 304 Norte é uma unidade de ensino onde prevalece uma gestão democrática e cidadã, favorecendo a presença de elementos de educação em direitos humanos no projeto político-pedagógico da escola, fato que contraria a hipótese desta pesquisa. 


\section{SUMÁRIO}

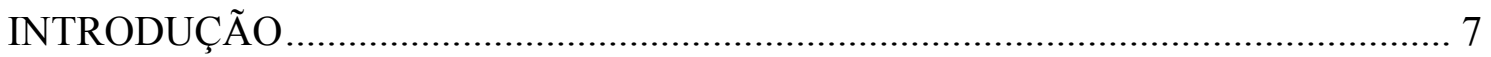

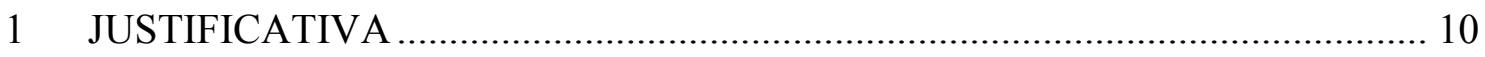

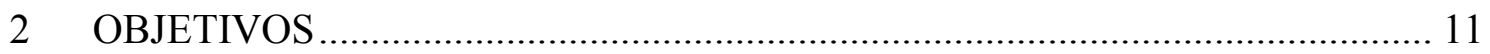

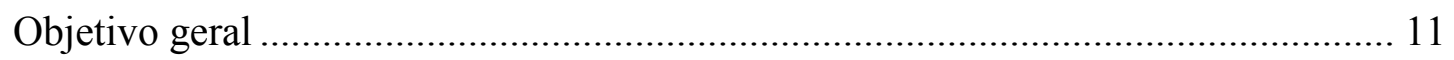

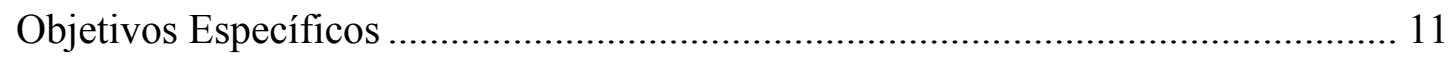

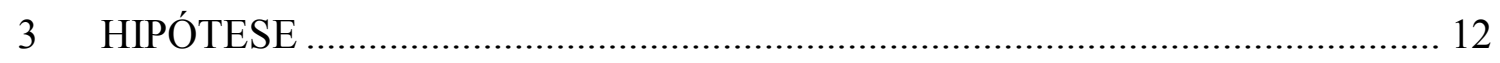

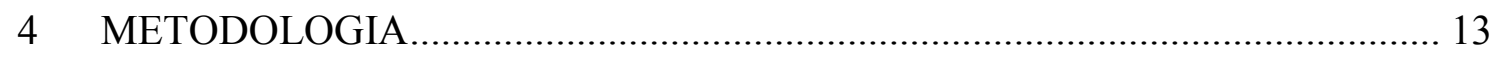

5 REFERENCIAL TEÓRICO......................................................................... 19

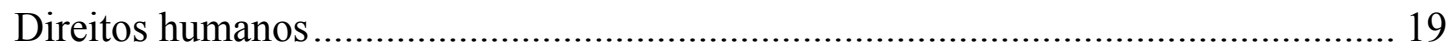

Papel da escola na promoção dos direitos humanos ..................................................... 24

Projeto político-pedagógico : um instrumento fundamental da promoção dos direitos humanos

6 Estudo de caso: a Escola Classe 304 Norte do DF .............................................. 36 
6.1.1 Perfil sócio-econômico e político-ideológico das docentes

6.1.2 Escola e comunidade 51

6.1.3 Escola, democracia e cidadania 55

6.1.4 Escola e educação em direitos humanos. 60

CONCLUSÃO 69

7 REFERÊNCIAS BIBLIOGRÁFICAS 70

8 ANEXO 74 


\section{INTRODUÇÃO}

Este trabalho se configura como pré-requisito para a conclusão do curso de bacharel em Serviço Social na Universidade de Brasília. O interesse pelo tema "Educação em Direitos Humanos" surgiu após a minha introdução no processo de pesquisa, ao cursar as disciplinas Pesquisa em Serviço Social 1 e 2. Nestas disciplinas, conduzidas pela orientadora desse trabalho de conclusão, levantaram-se dados sobre escolas públicas do DF e seus respectivos projetos político-pedagógicos. Foi feito um processo de escolha de dois Centros de Ensino baseado nessas informações que culminou numa perspectiva negativa em relação à formação dos alunos na área de educação em direitos humanos. Com o intuito dar continuidade aos estudos de casos das escolas públicas do DF, esse trabalho de conclusão se articulou com o projeto maior realizado nas disciplinas e mesmo diante de indícios de uma relação positiva da escola com a gestão democrática, preferiu-se que a hipótese ressaltasse os aspectos negativos dessa relação em função das experiências anteriores.

O eixo da pesquisa estava voltado para a questão da educação em direitos humanos, tendo como referência a proposta do Plano Nacional de Educação em Direitos Humanos, lançado pela Sub-Secretaria de Direitos Humanos em 2003. O objeto de estudo era investigar o projeto político-pedagógico das escolas públicas de educação básica do Distrito Federal e o modo como esse projeto estava ou não sendo utilizado para a formação dos alunos na área de educação em direitos humanos.

Antes de aprofundar no tema da pesquisa, é interessante delimitar o conceito de educação em direitos humanos conforme define o Plano Nacional de Educação em Direitos Humanos:

"um processo sistemático e multidimensional que orienta a formação do sujeito de direitos, articulando as seguintes dimensões: apreensão de conhecimentos historicamente construídos sobre direitos humanos e a sua relação com os contextos internacional, nacional e local; afirmação de valores, atitudes e práticas sociais que expressam a cultura dos direitos humanos em todos os espaços da sociedade; formação de uma consciência cidadã capaz de se fazer presente nos níveis cognitivo, social, ético e político; desenvolvimento de 
processos metodológicos participativos e de construção coletiva utilizando linguagens e materiais didáticos orientados à mudança de mentalidade - bem como práticas individuais e sociais que gerem ações e instrumentos em favor da defesa, promoção e ampliação dos direitos humanos" (CNEDH, 2006: 7).

Desse modo, a educação como um direito humano é também um meio indispensável para o acesso a outros direitos e ganha uma grande relevância para o desenvolvimento humano e as suas potencialidades, valorizando o respeito aos grupos socialmente excluídos, visando à efetivação da cidadania plena.

O Plano Nacional de Educação em Direitos Humanos traz uma introdução sobre direitos humanos, informando que este surgiu no Brasil como uma resposta às diversas formas de violência política vivenciadas nas décadas de 1960 e 1970. Foi na década de 1980, no período de redemocratização e mobilização social, com a preocupação de se criar uma nova cultura política, que o debate sobre direitos humanos e a formação para a cidadania vem alcançando mais espaço e relevância no país. Com a Constituição Federal de 1988, os direitos humanos são postos como fundamento do Estado Brasileiro.

Com a premissa "a educação em e para os direitos humanos é um direito fundamental do ser humano", a Organização das Nações Unidas estabeleceu a década da Educação em Direitos Humanos 1995/2004, com o objetivo de estimular governos e sociedade civil a construírem estratégias para a criação e o fortalecimento de programas de educação em direitos humanos ao nível internacional e nacional.

Novos mecanismos de proteção surgiram no cenário nacional, como por exemplo, o Plano Nacional de Educação em Direitos Humanos, que teve início em 2003 com a elaboração da sua primeira versão, como forma de orientar a construção de políticas, ações e programas comprometidos com uma cultura de paz e justiça social. Em 2006 foi elaborada a versão semifinal do plano, contando com a participação ampla da sociedade civil e comprometida com a consolidação de uma cultura de cidadania a ser efetivada com a adoção de políticas públicas nessa área. 
Em tempos difíceis e conturbados, com uma série de violações aos direitos humanos, tanto no campo dos direitos civis e políticos, quanto no dos direitos econômicos, sociais, culturais e ambientais, além de um descompasso entre os avanços no plano jurídico-institucional e a realidade concreta da efetivação dos direitos, faz-se necessária e urgente a educação em direitos humanos em todas as formas possíveis, como tarefa indispensável para a defesa e valorização de todos os direitos já conquistados.

Nesse trabalho será analisada a formação dos alunos de $1^{\mathrm{a}}$ a $4^{\mathrm{a}}$ séries na área de educação em direitos humanos, tendo como base a análise do projeto político-pedagógico de uma unidade educacional pública do Distrito Federal selecionada para estudo. 


\section{JUSTIFICATIVA}

Paulo Freire (1970) ensina que educar é um processo coletivo, recíproco e horizontal de cultivo do potencial das pessoas para torná-las conscientes, cidadãos pensantes, capazes de problematizar a realidade, de sentir as injustiças e as desigualdades como afrontas à sua própria dignidade e, partindo dos aspectos estruturais da sociedade, ser capaz de transformá-la. Nesse sentido, educar não significa inculcar conteúdos de cima para baixo, nem utilizar conhecimentos e informações pré-fabricadas para que os educandos recebam passivamente o seu conteúdo.

Candau (2000) afirma ser essencial a educação em direitos humanos para a construção de uma sociedade verdadeiramente democrática. Essa educação dever ser capaz de fortalecer a sociedade civil e orientar a construção da cidadania plena.

Nessa direção, o governo brasileiro tem o compromisso maior de promover a educação de qualidade para todos, entendida como direito humano essencial. Assim, a universalização do ensino fundamental, a ampliação da educação infantil, do ensino médio, da educação superior e a melhoria da qualidade em todos os níveis e modalidades de ensino são ações fundamentais.

Esse é um desafio central do mundo que tem uma importância redobrada em países da América Latina, caracterizada por graves e sistemáticas violações aos direitos humanos, expressando a precariedade e fragilidade dos Estados. Nesse sentido, é necessário incluir e implementar o tema nos currículos, de modo a coexistir com as demais disciplinas e proporcionar uma nova cultura de dignidade do ser humano.

Esta pesquisa se justifica a partir do entendimento que educar em direitos humanos é fundamental para a construção de um processo de cidadania, que leve em consideração, entre outros aspectos, a existência do "outro" como sujeito de direito, a quem devemos respeitar e desconstruir preconceitos e visões limitadas, aceitando a pluralidade cultural e, ao mesmo tempo, educar na identidade e 
reconhecimento da dignidade humana.

A adoção de um projeto político-pedagógico comprometido com os direitos humanos reafirma o entendimento de que os alunos são capazes de adotar atitudes, comportamentos e crenças voltadas para a cidadania, a tolerância, o respeito, a solidariedade, contribuindo para efetivar uma cultura de paz. Dessa forma, é de suma importância conhecer o projeto político-pedagógico das escolas, e sua contribuição para a formação social, cultural, política, profissional e humana dos alunos.

\section{OBJETIVOS}

\section{Objetivo geral}

Investigar o projeto político-pedagógico da Escola Classe 304 Norte de Brasília, levando em consideração sua importância para a formação dos alunos na área da educação em direitos humanos.

\section{Objetivos Específicos}

\section{a) Finalidade da escola}

Conhecer o projeto político-pedagógico da escola, tendo em vista sua contribuição para a formação social, cultural, política, profissional e humana dos alunos e verificar sua conformidade com as propostas do Plano Nacional de Educação em Direitos Humanos .

\section{b) Estrutura organizacional}

Analisar criticamente a estrutura administrativa (a gestão de recursos humanos, físicos, financeiros) e pedagógica das escolas públicas do DF (a constituição e distribuição de poder, ensino/aprendizagem) - Estrutura Organizacional. 


\section{c)Currículo}

Verificar como o currículo escolar se caracteriza em seu aspecto formal e oculto (valores e normas dominantes), avaliando se há ou não uma orientação emancipatória no mesmo .

\section{d)Tempo escolar}

Avaliar a qualidade do trabalho pedagógico desenvolvido tendo em vista a formação dos alunos na área de educação em direitos humanos .

\section{e) Processo de decisão}

Verificar a distribuição e descentralização do processo decisório e a existência de estímulo à participação dos professores, pais e alunos em tal processo .

\section{f)Relações de trabalho}

Pesquisar sobre a natureza das condições de trabalho existentes nas escolas públicas do DF .

\section{g) Avaliação}

Conhecer o processo de avaliação existente nas escolas públicas do DF, levando em consideração a existência de três momentos: a problematização da realidade escolar, a compreensão crítica da realidade, propostas de alternativas de ação Avaliação.

\section{HIPÓTESE}

O projeto político-pedagógico da Escola Classe 304 Norte não reflete as condições necessárias para a formação dos alunos na área de educação em direitos 
humanos.

\section{METODOLOGIA}

Este trabalho teve o propósito de conhecer a importância da educação em direitos humanos no projeto político-pedagógico de uma das escolas públicas do DF. Isso implicou em analisar a realidade escolar, partindo de uma perspectiva dialética histórico-estrutural, de modo a estudar as diversas categorias capazes de captar os conflitos e tensões existentes nessa instituição social.

Essa perspectiva dialética está aberta para o permanente movimento da realidade, pautado na incerteza, na ambivalência e na incompletude dessa dinâmica, utilizando categorias analíticas que permitem a mediação entre o pensamento e esta realidade em constante transformação.

Em primeiro lugar, é importante considerar a escola como uma totalidade, cuja dinâmica articula convergências e divergências; em segundo, a historicidade que envolve o contexto institucional, social, político, econômico e cultural onde a escola se encontra e em terceiro, a relação entre teoria e prática da realidade escolar centrada nos sujeitos que traçam a sua trajetória.

Essa pesquisa tem como objeto de estudo um problema de natureza qualitativa, no entanto, também foram utilizados dados de natureza quantitativa, de modo a complementar a coleta de dados relacionada ao problema escolhido. A pesquisa qualitativa, segundo Demo (2001), está referida a temas que se interessam mais pela intensidade do que pela extensão dos fenômenos. Ela não se opõe aos formatos de pesquisa quantitativa, uma vez que a dicotomia entre quantidade e qualidade está superada, apenas focaliza mais de perto os horizontes qualitativos, buscando o aprofundamento. Acrescenta o autor:

"A informação qualitativa é, assim, comunicativamente trabalhada e retrabalhada, para que duas condições sejam satisfeitas: do ponto de vista do entrevistado, ter a confiança de que se expressou como queria; do ponto de vista do entrevistador, ter a confiança de que 
obteve o que procurava ou de que realizou a proposta" (DEMO, 2001: $31)$.

"O analista qualitativo observa tudo, o que é ou não dito: os gestos, o olhar, o balançar da cabeça, o meneio do corpo, o vaivém das mãos, a cara de quem fala ou deixa de falar, porque tudo pode estar imbuído de sentido e expressar mais do que a própria fala. Pois a comunicação humana é feita de sutilezas, não de grosserias. Por isso é impossível reduzir o entrevistado a objeto" (DEMO, 2001: 34).

A pesquisa qualitativa é orientada para a análise de casos concretos em sua particularidade temporal e local, partindo de expressões e atividades das pessoas em seus contextos locais. Coaduno com a idéia do autor de que entre quantidade e qualidade não há dicotomia, pois são faces diferenciadas do mesmo fenômeno. Nesse processo de pesquisa, elas foram tomadas como complementares.

O objeto empírico da pesquisa foi a Escola Classe 304 Norte pertencente à rede escolar pública de educação básica do Plano Piloto, responsável pela formação dos alunos de $1^{\mathrm{a}}$ a $4^{\mathrm{a}}$ séries. Os informantes centrais são professores, diretores, coordenadores e orientadores educacionais, além de alunos e familiares.

A partir do conhecimento da orientadora deste trabalho sobre o perfil dos estabelecimentos de ensino de $1^{\mathrm{a}}$ a $4^{\mathrm{a}}$ séries do Plano Piloto, procedeu-se à escolha de uma escola com experiência na área de educação em direitos humanos. Foi selecionada a Escola Classe da 304 Norte do Plano Piloto, tendo em vista as inúmeras informações levantadas sobre a presença de uma gestão democrática e da participação da comunidade escolar.

Nesta unidade de ensino, foram escolhidos os seguintes informantes: professores (10 do universo de 14); diretor (1), coordenador pedagógico (1) e orientador educacional (1); alunos (1 grupo focal com 8 alunos da $3^{\mathrm{a}}$ e $4^{\mathrm{a}}$ séries matutino. Do total de 318 alunos em 14 turmas do período matutino e vespertino, foram selecionados dois alunos de cada turma da $3^{\mathrm{a}}$ e $4^{\mathrm{a}}$ séries do matutino por serem alunos com mais idade, além do período matutino se apresentar como mais favorável para a realização do grupo focal.A escola tinha no momento da pesquisa de campo 1 turma da $3^{\mathrm{a}}$ série do matutino (28 alunos) e 3 turmas da $4^{\mathrm{a}}$ série do matutino (63 alunos) .Foi 
formado também 1 grupo focal com 7 pais, incluindo membros da APM. Para complementar as informações, foram coletados documentos junto à direção da escola, de modo a oferecer um contraponto ao material levantado no trabalho de campo.

Foi adotado o método de estudo de caso, referido a uma análise intensiva de uma situação particular. Yin (apud BRESSAN, 2007: 01) afirma que "o estudo de caso é uma inquirição empírica que investiga um fenômeno contemporâneo dentro de um contexto da vida real, quando a fronteira entre o fenômeno e o contexto não é claramente evidente e onde múltiplas fontes de evidência são utilizadas". A preferência pelo uso do estudo de caso deve ser dada quando se estuda evento contemporâneo, em situações onde os comportamentos relevantes não podem ser manipulados, mas onde é possível fazer observações diretas e entrevistas sistemáticas.

O estudo de caso é preferido especialmente quando o tipo de questão de pesquisa é da forma "como" e "por que"; e o controle do investigador sobre os eventos é muito reduzido, ou quando o foco temporal está em fenômenos contemporâneos dentro do contexto de vida real (BRESSAN, 2007: 2).

Os objetivos do método de estudo de caso, segundo McClintock (Apud BRESSAN, 2007: 2) são os seguintes: “(...) são (1) capturar o esquema de referência e a definição da situação de um dado participante... (2) permitir um exame detalhado do processo organizacional e (3) esclarecer aqueles fatores particulares ao caso que podem levar a um maior entendimento da causalidade".

De forma sintética, Yin (apud BRESSAN, 2007: 3) apresenta quatro características do método do estudo de caso: "1. para explicar ligações causais nas intervenções na vida real que são muito complexas para serem abordadas pelos 'surveys' ou pelas estratégias experimentais; 2.para descrever o contexto da vida real no qual a intervenção ocorreu; 3.para fazer uma avaliação, ainda que de forma descritiva, da intervenção realizada; 4.para explorar aquelas situações onde as intervenções avaliadas não possuam resultados claros e específicos". 
Um dos instrumentos de coleta de dados também utilizado nessa pesquisa é a observação participante, que "consiste na participação real do pesquisador com a comunidade ou grupo" (MARCONI e LAKATOS, 2002: 90). Há uma incorporação do investigador ao grupo. No caso em apreço, me integrei à escola por seis meses, fiz a observação participante, bem como entrevistas e grupos focais, além de participar de reuniões com a finalidade de obter informações sendo muito bem aceita por toda a equipe pedagógica, de professores, alunos e pais.

Esta técnica foi escolhida por ser a mais indicada para que se possa conhecer melhor a realidade escolar, na medida em que permite a familiarização com o local de pesquisa e garante uma compreensão mais profunda das vivências cotidianas presentes no comportamento dos professores, alunos, pais, gestores e funcionários. Ao observar as atividades, interesses e sentimentos dos informantes, o investigador compreende melhor o cotidiano dessas pessoas, de modo dar uma forma mais consistente à observação participante e maior nitidez aos depoimentos.

No geral, a observação participante, como diz Flick (2004: 157),

"elucida o dilema entre a participação crescente no campo - da qual a compreensão torna-se meramente científica e verificável. Além disso, esse método ainda aproxima-se de uma concepção da pesquisa qualitativa como um processo, já que presume um período mais longo no campo e em contato com pessoas e contextos a serem estudados, enquanto que as entrevistas, na maioria das vezes, continuam sendo encontros exclusivos".

Também foi utilizada a entrevista, que proporciona uma interação social entre o entrevistador e o entrevistado e garante maior qualidade dos dados levantados. Um dos objetivos desta pesquisa é a averiguação dos fatos, ou seja, descobrir se as pessoas que estão de posse de certas informações são capazes de compreendê-las. Além disso, a entrevista capta as opiniões sobre os fatos; a determinação de sentimentos; a descoberta de planos de ação, e inclusive os motivos conscientes que podem influenciar opiniões, sentimentos, sistemas ou condutas (MARCONI e LAKATOS, 2002: 93). 
O roteiro de entrevistas tem caráter estruturado, ou seja, foi adotado um roteiro previamente estabelecido, com perguntas abertas e fechadas, incluindo questões sobre a finalidade da escola, a estrutura organizacional, o currículo, o controle social, o tempo escolar, o processo de decisão, as relações de trabalho e a avaliação, configurando seis tópicos: I) Perfil sócio-econômico; II) Perfil político-ideológico; III) Escola e comunidade; IV) Escola, democracia e cidadania; V) Escola e educação em direitos humanos; VI) Educação em direitos humanos e o projeto político-pedagógico.

Segundo Marconi e Lakatos (2002: 95), como técnica de pesquisa, a entrevista oferece inúmeras vantagens e algumas desvantagens. Nessa pesquisa foram levadas em consideração as seguintes vantagens: "pode ser utilizada em todos os segmentos da população; fornece uma amostragem muito melhor da população geral, já que o entrevistado não precisa ler ou escrever; há maior flexibilidade, pode repetir e esclarecer perguntas; oferece maior oportunidade para avaliar atitudes, condutas, podendo o entrevistado ser observado naquilo que diz e como diz; dá oportunidade para a obtenção de dados que não se encontram em fontes documentais; há a possibilidade de conseguir informações mais precisas; permite que os dados sejam quantificados e submetidos a tratamento estatístico".

Foram levadas em consideração também as seguintes limitações: dificuldade de expressão e comunicação de ambas as partes; incompreensão do informante, do significado das perguntas, que pode levar a uma falsa interpretação; possibilidade do entrevistado ser influenciado pelo entrevistador; disposição do entrevistado em dar as informações necessárias; retenção de algum dado importante, receando que fosse revelada; pequeno grau de controle sobre a coleta de dados e ocupa muito tempo, sendo difícil ser realizada (MARCONI e LAKATOS, 2002: 95). Mesmo diante de todas essas limitações, ainda assim não impediu que fosse escolhida essa técnica de pesquisa.

O grupo focal, também utilizado, é uma técnica que, segundo Powell e Single (apud GATTI, 2005: 7), é "um conjunto de pessoas selecionadas e reunidas por pesquisadores para discutir e comentar um tema, que é objeto de pesquisa, a partir de 
sua experiência pessoal”. Acrescenta que a ênfase recai sobre a interação dentro do grupo e não em perguntas e respostas entre moderador e membros do grupo. Há interesse não somente no que as pessoas pensam e expressam, mas também em como elas pensam e porque pensam o que pensam.

Morgan e Krueger (apud GATTI, 2005: 9) afirmam que a pesquisa com grupos focais tem por objetivo "captar, a partir das trocas realizadas no grupo, conceitos, sentimentos, atitudes, crenças, experiências e reações, de um modo que não seria possível com outros métodos". Dessa forma, o grupo focal permite conseguir boa quantidade de informação em um período de tempo mais curto, além de trazer à tona respostas mais completas e verificar a lógica ou as representações que conduzem à resposta. Permite ainda a compreensão de idéias partilhadas por pessoas no dia-a-dia e dos modos pelos quais os indivíduos são influenciados pelos outros.

A escolha desta técnica foi importante para dar maior visibilidade às divergências, contradições e contraposições existente em torno do problema em estudo. Foram realizados dois grupos focais: um composto por oito alunos da $3^{\mathrm{a}}$ e $4^{\mathrm{a}}$ séries e outro com sete pais. O primeiro grupo foi escolhido por indicação da direção e das professoras e ocorreu da seguinte maneira: a diretora passou nas salas de $3^{\mathrm{a}}$ e $4^{\mathrm{a}}$ séries, explicou e perguntou quem gostaria de participar do grupo focal; depois a turma decidiu por meio de conversa quem iria; nas turmas com muitos alunos interessados em participar foi feito votação. O segundo, foi resultado do convite feito pela direção da escola a todos os pais das crianças de $3^{\mathrm{a}}$ e $4^{\mathrm{a}}$ séries, especialmente àqueles que participavam mais intensamente das atividades da escola. A discussão fluiu a partir das questões elaboradas em roteiros e foi coordenada pela orientadora desta dissertação. A participação equilibrada dos membros nos dois grupos focais permitiu alcançar sucesso nos dados levantados.

Com esses instrumentos de coletas de dados foi possível mapear as dificuldades para a implementação da educação em direitos humanos na proposta pedagógica da escola, ficando mais fácil para a direção da escola e, posteriormente, para a Secretaria de Educação do DF suprir as carências identificadas, de modo a tornar a 
questão dos direitos humanos entrelaçada com as temáticas cotidianas da educação básica. A pesquisa de campo foi uma intervenção na escola de modo a proporcionar um momento de reflexão para os professores, equipe pedagógica, pais e alunos.O resusltado final da pesquisa será entregue à direção da escola, de maneira que possa haver um retorno do trabalho desenvolvido nesta Escola Classe .

\section{REFERENCIAL TEÓRICO}

\section{Direitos humanos}

Direitos Humanos são aqueles considerados fundamentais a todos os seres humanos, sem quaisquer distinções de sexo, nacionalidade, etnia, cor da pele, faixa etária, classe social, profissão, condição de saúde física e mental, opinião política, religião, nível de instrução e julgamento moral (BENEVIDES, 2000: 5 e 6).

Os direitos humanos são naturais e universais, pois estão profundamente ligados à essência do ser humano, independentemente de qualquer ato normativo, e valem para todos; são interdependentes e indivisíveis, pois não podemos separá-los, aceitando apenas os direitos individuais, ou só os sociais. Direitos humanos são históricos, pois foram sendo reconhecidos e consagrados em determinados momentos históricos, e vão crescendo em abrangência e em profundidade, até que se consolidem na consciência universal.

A Declaração Universal dos Direitos Humanos da ONU, de 1948, desencadeou um processo de mudança no comportamento social e a produção de instrumentos e mecanismos internacionais de direitos humanos que foram incorporados ao ordenamento jurídico dos países que assinaram. No Brasil, a Constituição Federal de 1988 formalmente consagrou o Estado Democrático de Direito e reconheceu, entre seus fundamentos, a dignidade da pessoa humana e os direitos ampliados da cidadania (civis, políticos, econômicos, sociais, culturais).

O Estado brasileiro tem como princípio a afirmação dos direitos 
humanos como universais, indivisíveis e interdependentes e, para sua efetivação, todas as políticas públicas devem considerá-los na perspectiva da construção de uma sociedade baseada na promoção da igualdade de oportunidades e da equidade, no respeito à diversidade e na consolidação de uma cultura democrática e cidadã. Nessa direção, o governo brasileiro tem o compromisso maior de promover uma educação de qualidade para todos, entendida como direito humano essencial.

Ocorre que o quadro que se apresenta nos dias de hoje é de uma série de violações de direitos humanos, tanto no campo dos direitos civis e políticos quanto no dos direitos econômicos, sociais, culturais e ambientais. Em tempos difíceis, marcados por inúmeros conflitos, nada mais necessário que educar em direitos humanos para a defesa, o respeito, a promoção e a valorização desses direitos. A educação em direitos humanos, ao longo de todo o processo de redemocratização e de fortalecimento do regime democrático, tem buscado contribuir para dar sustentação às ações de promoção, proteção e defesa dos direitos humanos, e de reparação das violações.

Direitos humanos são fundamentais porque são indispensáveis para a vida com dignidade. Porque a dignidade é central no processo educativo?

Los derechos humanos son un ámbito propicio para encarnar y recrear valores, porque sitúa a la dignidad humana como valor fundante de una ética y una moral. Desde la vigencia en los derechos humanos se articulan los valores de la libertad, la justicia y la igualdad, la democracia, el pluralismo y el respeto a la diversidad, la tolerancia, la no-discriminación, la solidaridad y el reconocimiento del Otro individual y colectivo como un legítimo otro (MAGENDZO, 2006: 24).

A dignidade do ser humano não repousa apenas na racionalidade, pois no processo educativo procuramos atingir a razão, mas também a emoção, isto é, corações e mentes - pois a pessoa humana não é apenas um ser que pensa e raciocina, mas que chora e ri, é capaz de amar e odiar, de sentir indignação e enternecimento e é capaz da criação estética. Só o ser humano é dotado de vontade, de preferências valorativas, de autonomia, de autoconsciência como o oposto da alienação e tem a memória e a consciência de sua própria subjetividade, de sua própria história no tempo 
e no espaço. É o único ser histórico, pois é o único que vive em perpétua transformação pela memória do passado e pelo projeto do futuro.

O que significa trabalhar com educação em direitos humanos? Segundo Benevides (2000: 1) há três pontos essenciais: primeiro, é uma educação de natureza permanente, continuada e global. Segundo, é uma educação necessariamente voltada para a mudança, e terceiro, é uma inculcação de valores, para atingir corações e mentes e não apenas instrução, meramente transmissora de conhecimentos. Acrescentese que ou esta educação é compartilhada por aqueles que estão envolvidos no processo educacional - os educadores e os educandos - ou ela não será educação e muito menos educação em direitos humanos. Podemos dizer, então, que são premissas: a educação continuada, a educação para a mudança e a educação compreensiva, no sentido de ser compartilhada e de atingir tanto a razão quanto a emoção.

A Educação em Direitos Humanos, pelo que se depreende do Plano Nacional de Educação em Direitos Humanos de 2006, é essencialmente a formação de uma cultura de respeito à dignidade humana através da promoção e da vivência dos valores da liberdade, da justiça, da igualdade, da solidariedade, da cooperação, da tolerância e da paz. Portanto, a formação desta cultura significa criar, influenciar, compartilhar e consolidar mentalidades, costumes, atitudes, hábitos e comportamentos que decorrem, todos, daqueles valores essenciais citados - os quais devem se transformar em práticas.

Como afirma Magendzo (2006:23):

Se ha definido el término de educación en derechos humanos a la práctica educativa que se funda en el reconocimiento, la defensa, respecto y la promoción de los derechos humanos y que tiene por objeto desarrollar en los individuos y los pueblos sus máximas capacidades como sujetos de derechos y brindarles las herramientas y elementos para hacerlos efectivos. Se trata de una formación que reconoce las dimensiones históricas, políticas y sociales de la educación y que se basa en los valores, principios, mecanismos e instituciones relativos a los derechos humanos en su integralidad y en su relación de interdependencia e indivisibilidad con la democracia, el desarrollo y la paz. 
Fala-se em cultura nos termos da mudança cultural, uma mudança que possa realmente mexer com o que está mais enraizado nas mentalidades, muitas vezes marcadas por preconceitos, discriminação, pela não aceitação dos direitos de todos e da diferença. Implica a derrocada de valores e costumes arraigados entre nós, decorrentes de vários fatores historicamente definidos: nosso longo período de escravidão, que significou exatamente a violação de todos os princípios de respeito à dignidade da pessoa humana, a começar pelo direito à vida; nossa política oligárquica e patrimonial; nosso sistema de ensino autoritário, elitista e com uma preocupação muito mais voltada para a moral privada do que para a ética pública; nossa complacência com a corrupção, dos governantes e das elites, assim como em relação aos privilégios concedidos aos cidadãos ditos de primeira classe ou acima de qualquer suspeita; nosso descaso com a violência, quando ela é exercida exclusivamente contra os pobres e os socialmente discriminados; nossas práticas religiosas essencialmente ligadas ao valor da caridade em detrimento do valor da justiça; nosso sistema familiar patriarcal e machista; nossa sociedade racista e preconceituosa contra todos os considerados diferentes; nosso desinteresse pela participação cidadã e pelo associativismo solidário; nosso individualismo consumista, decorrente de uma falsa idéia de "modernidade" (BENEVIDES, 2006: 2).

A educação para os direitos humanos, ao fundar-se no reconhecimento e proteção dos valores da pessoa humana, justifica a sua profundidade, abrangência, importância e necessidade. Profundidade por estabelecer um sistema de valores universais tanto para as pessoas quanto para os Estados poderem embasar e avaliar suas ações. Abrangência por englobar a educação cívica, a educação para a igualdade, para o respeito à diversidade, para a tolerância, para a paz etc. Importância, porque os cidadãos com consciência dos seus direitos sabem como garanti-los, não sendo considerada menos importante que as outras. Necessidade, por abranger as questões éticas, jurídicas, bem como os problemas reais, discutindo e intervindo sobre eles (AFONSO, 2006: 5).

Quando falamos em educação em direitos humanos falamos também em educação para a cidadania. É bastante comum a idéia de educação para cidadania ser entendida como se fosse meramente uma educação moral e cívica. Torna-se 
necessário entender educação para a cidadania como formação do cidadão participativo e solidário, consciente de seus deveres e direitos - e, então, associá-la à educação em direitos humanos. Só assim teremos uma base para uma visão mais global do que seja uma educação democrática, que é, afinal, o que desejamos com a educação em direitos humanos, entendendo democracia como "um regime alicerçado na soberania popular, na justiça social e no respeito integral aos direitos humanos" (PNEDH, 2006), ou seja, como o regime da soberania popular com pleno respeito aos direitos humanos.

\section{O que se pretende com a educação em direitos humanos? Segundo}

o Plano Nacional de Educação em Direitos Humanos de 2006, o aprendizado deve estar ligado à vivência do valor da igualdade em dignidade e direitos para todos e deve propiciar o desenvolvimento de sentimentos e atitudes de cooperação e solidariedade. Ao mesmo tempo, a educação para a tolerância se impõe como um valor ativo vinculado à solidariedade e não apenas como tolerância passiva da mera aceitação do outro, com o qual pode-se não estar solidário. Em seguida, o aprendizado deve levar ao desenvolvimento da capacidade de se perceber as conseqüências pessoais e sociais de cada escolha. Ou seja, deve levar ao senso de responsabilidade. Esse processo educativo deve, ainda, visar à formação do cidadão participante, crítico, responsável e comprometido com a mudança daquelas práticas e condições da sociedade que violam ou negam os direitos humanos. Mais ainda, deve visar à formação de personalidades autônomas, intelectual e afetivamente, sujeitos de deveres e de direitos, capazes de julgar, escolher, tomar decisões, serem responsáveis e prontos para exigir que não apenas seus direitos, mas também os direitos dos outros sejam respeitados e cumpridos.

Candau (2006: 2) coloca a necessidade e a urgência de se construir uma cultura dos direitos humanos a partir do cotidiano, capaz de transformar profundamente as mentalidades e gerar novas práticas sociais. Nessa perspectiva, o papel da educação é fundamental. Formar para a cidadania e para a democracia é um objetivo irrenunciável das diferenças das práticas educativas, no âmbito formal e informal, e passa necessariamente pela afirmação teórica e prática dos direitos humanos.

Uma proposta metodológica de educação em direitos humanos, 
acrescenta Candau (2006), necessita de alguns eixos articuladores do trabalho que se pretende executar. Para transformar a realidade, se faz necessário trabalhar o cotidiano em toda a sua complexidade. O que se vê muitas vezes na nossa sociedade é o processo educativo não levar em consideração o contexto social em que os educandos estão inseridos. As práticas educativas e a vida parecem ser dois mundos que se ignoram. Para ela, é preciso que a prática educativa afirme uma pedagogia que promova convicções firmes e conscientes de que as violações não são fenômenos naturais, mas realidades construídas historicamente, e esta deve expressar-se na forma de trabalhar a dimensão ética da educação.

A necessidade de formar cidadãos empenhados na superação das desigualdades sociais existentes desafia a ação educativa e o debate acadêmico na construção de instrumentos políticos e pedagógicos que potencializem as práticas

políticas e educativas formais e informais. Por fim, a mobilização global para a educação em direitos humanos está imbricada no conceito de educação para uma cultura democrática, na compreensão dos contextos nacional e internacional, nos valores da tolerância, da solidariedade, da justiça social e na sustentabilidade, na inclusão e na pluralidade.

\section{Papel da escola na promoção dos direitos humanos}

Desde a aprovação da Declaração Universal dos Direitos Humanos, a escola é convocada a exercer um papel-chave na divulgação de direitos humanos, uma vez que a sua finalidade é fazer crescer o indivíduo em dignidade e afirmar a alteridade. A escola é local de estruturação de concepções de mundo e de consciência social, de circulação e de consolidação de valores, de promoção de diversidade cultural, da formação para a cidadania, de constituição de sujeitos sociais e de desenvolvimento de práticas pedagógicas.

De acordo com o Plano Nacional de Educação em Direitos Humanos de 2006, são princípios norteadores da educação em direitos humanos na educação básica: desenvolver uma cultura de direitos humanos em todos os espaços sociais; assegurar que os objetivos e práticas a serem adotados sejam coerentes com os 
valores e princípios da educação em direitos humanos; por seu caráter coletivo, democrático e participativo, a educação em direitos humanos deve ocorrer em espaços marcados pelo entendimento mútuo, respeito e responsabilidade; deve estruturar-se na diversidade cultural e ambiental, garantindo a cidadania, o acesso ao ensino, permanência e conclusão, a equidade e a qualidade da educação; deve ser o eixo fundamental da educação básica e permear o currículo, a formação inicial e continuada dos profissionais da educação, o projeto político-pedagógico da escola, os materiais didático-pedagógicos, o modelo de gestão e a avaliação; e por último, a prática escolar deve assegurar o caráter transversal dos direitos humanos e a relação dialógica entre os diversos atores sociais.

A luta pelos direitos humanos é, segundo Santiago (2004), um desafio. Sua efetivação passaria por uma prática pedagógica que buscaria projetos de realização participante para resolução de conflitos de forma cordial, onde temas cotidianos como discriminação, racismo, exclusão e opressão, seriam tratados com uma pedagogia que busca a necessária adequação da instituição escolar às mudanças socioculturais e político-econômicas desse século.

A educação em direitos humanos vai além de uma aprendizagem cognitiva, incluindo o desenvolvimento social e emocional de quem se envolve no processo ensino-aprendizagem. A educação deve ocorrer na comunidade escolar em interação com a comunidade local.

Assim, a educação em direitos humanos, pelo que prevê o Plano Nacional de Educação em Direitos Humanos, deve abarcar questões referentes à educação formal, à escola, aos procedimentos pedagógicos, às agendas e instrumentos que possibilitem uma ação pedagógica conscientizadora e libertadora, voltada para o respeito e valorização da diversidade, aos conceitos de sustentabilidade e de formação da cidadania ativa.

Segundo Falkembach (2004), a educação precisa ser mantida a um nível permanente de reflexão, já que entendemos que a escola não é o único local de 
aprendizagem. O ser humano tem um grande potencial de criar, recriar e transformar o seu pensamento devido ao constante processo de mudança. Assim, a escola precisa ter uma visão consciente, prático-reflexiva, para acompanhar as mudanças e agir de uma forma mais concreta na realidade. A escola é instrumento pedagógico de mudança, um espaço privilegiado para começar essa reflexão, mas isso não pode ficar somente no campo da teoria, deve propor algo concreto e vinculado com um conteúdo político de participação.

\begin{abstract}
"Não é apenas na escola que se produz e reproduz o conhecimento, mas é nela que esse saber aparece sistematizado e codificado. Ela é o espaço onde se definem a ação institucional pedagógica e a prática e vivência dos direitos humanos. Nas sociedades contemporâneas, a escola é o principal lócus de estruturação de concepções de mundo e de consciência social, de circulação e consolidação de valores, da formação para a cidadania, de constituição de sujeitos sociais e de desenvolvimento das práticas pedagógicas. O processo formativo que nela se realiza supõe a pluralidade e a alteridade, isto é, necessária liberdade para o exercício da crítica, da criatividade e para o debate de idéias e para o reconhecimento, respeito, promoção e valorização da diversidade" (CNEDH, 2006; 12).
\end{abstract}

A participação começa quando se aplicam as teorias refletidas no cotidiano da comunidade escolar, pois é no cotidiano que as raízes históricas são apontadas para o futuro, transformando o social, recuperando e construindo a identidade da escola e trabalhando os educadores, os educandos e a família.

Segundo Alvarez (2002:13), para se obter uma efetiva participação na educação é necessário um capital social bem desenvolvido, como ele mesmo conceitua: "la infraestructura de vida cívica y comunitaria necesaria para generar normas de reciprocidad y compromiso cívico, es decir, para desarrollar las características de la organización social que facilitan la coordinación y cooperación para beneficio mutuo".

Entretanto, na realidade, muitos dos professores, mesmo que em seus discursos se mostrem abertos ao diálogo com a comunidade, de fato acabam por colocar uma grande quantidade de obstáculos à participação. As melhorias alcançadas na escola, por meio da participação da comunidade escolar, recaem no campo das questões materiais e financeiras relacionadas à organização funcional da escola. As questões 
teórico-práticas, de cunho didático-pedagógico são abordadas de maneira superficial, caracterizando muito mais uma participação instrumental do que substantiva.

Existem inúmeras formas de participação, como, por exemplo, examinar os problemas da escola conjuntamente, buscando soluções, estabelecer planos de ação, tomar decisões democraticamente de forma que todas as instâncias participem, um esforço conjunto para se alcançar as metas e objetivos propostos, compartilhando e não delegando as responsabilidades uns para os outros, mas tendo compromisso para com a escola.

A Lei de Diretrizes e Bases da Educação representa um significativo progresso, já que pela primeira vez um documento legal apresenta referências explícitas sobre a necessidade de que cada escola, no exercício de sua autonomia, elabore e execute coletivamente a sua própria proposta pedagógica. O artigo 12, inciso I estabelece como incumbência primordial da escola a elaboração de sua proposta pedagógica e os artigos 13, inciso I e 14, incisos I e II estabelecem que tal proposta é uma tarefa coletiva, na qual devem colaborar professores, outros profissionais da educação e as comunidades escolar e local. Nesse sentido, a lei evidencia a necessidade de desburocratizar a educação, promovendo a descentralização do sistema e imprimindo maior autonomia aos estados, municípios e às escolas.

O processo de descentralização foi entendido "muito mais como transferência de responsabilidades pela gestão e manutenção das escolas, obedecidas as normas e diretrizes governamentais, do que como deslocamento do eixo de poder permitindo que as políticas e as decisões sejam formuladas via participação" (LIMA e VIRIATO, 2007: 7). A autonomia não é apenas outorgada por instrumentos legais, mas, sobretudo conquistada e construída.

Para alcançarmos um melhor desenvolvimento é necessário o fortalecimento do capital social. Isso ajuda a manter o diálogo necessário em uma sociedade mais aberta e democrática. A escola é o local mais apropriado para a criação de uma consciência quanto à importância de trabalhar na construção desse capital. 
Trata-se, portanto, da busca de uma qualidade para a educação, voltada para a construção do conhecimento e que reconhece a importância deste para a emancipação dos sujeitos e o exercício da cidadania. Isso significa colocar a discussão sobre o papel da escola e, conseqüentemente, sobre o projeto político-pedagógico que ela representa, em dimensão diferente daquela que, em décadas passadas, questionava apenas o papel reprodutor da educação escolarizada. É necessário "reinstituir" a escola com base em um novo paradigma que, ao revolucionar as concepções de conhecimento, a visão do mundo, os valores, imprima uma nova lógica ao ensino e aos elementos da prática educativa (SANTIAGO, 2004:160).

Com a promulgação da Lei de Diretrizes e Bases resgataram-se as preocupações pedagógicas, dando uma autonomia financeira, administrativa e pedagógica às escolas. É o que Mello (2002:78-85) chama de gestão democrática e gestão da aprendizagem. A gestão da aprendizagem ocorre no sentido de dar às escolas a liberdade e as responsabilidades para elaborar a proposta pedagógica, incluindo currículo e organização escolar, e aos docentes, a incumbência de zelar pela aprendizagem de seus alunos. A aprendizagem nesse contexto é entendida como a aquisição de competências necessárias para que o indivíduo se insira na sociedade de forma justa e equilibrada, para que possa ser um indivíduo com personalidade própria e ao mesmo tempo coletiva. Para tanto, a aprendizagem deve estar centrada nos quatro pilares propostos pela Comissão Internacional de Educação da UNESCO, que norteiam as políticas educacionais do mundo todo: aprender a conhecer, a fazer, a ser, a conviver.

Conhecer no sentido de, não tanto a aquisição de um repertório de saberes codificados, mas antes o domínio dos próprios instrumentos do conhecimento por ser considerado, simultaneamente, como um meio e como uma finalidade da vida humana. Fazer no sentido de como ensinar o aluno a pôr em prática os seus conhecimentos e como adaptar a educação ao trabalho futuro quando não se pode prever qual será a sua evolução. Ser, para melhor desenvolver a sua personalidade e estar à altura de agir com cada vez maior capacidade de autonomia, de discernimento e de responsabilidade pessoal. Conviver, desenvolvendo a compreensão do outro e a percepção das interdependências, realizar projetos comuns e preparar-se para gerir conflitos, no respeito pelos valores do pluralismo, da compreensão mútua e da paz (DELORS, 1999: 
89-102). Dessa forma, muda-se o paradigma do ensino para a aprendizagem, ou seja, desloca-se o eixo da liberdade de ensino para o direito de aprender.

A gestão democrática, na busca de uma efetiva autonomia e democratização da escola pública, implica em mudanças estruturais e funcionais dentro de um novo paradigma organizacional muito bem explicado, no que Garcia (in TORRES, 2001:267) chama de teoria da ação comunicativa de Habermas. Os pressupostos procedimentais necessários para concretizar essas mudanças dentro da prática escolar associam o desenvolvimento do projeto político-pedagógico com os processos de gestão democrática, ou seja, asseguram o planejamento participativo, diálogo e interatividade, de forma a não separar as pessoas que decidem das que executam.

Será por meio do projeto político-pedagógico que a escola se organizará de forma articulada, resgatando o seu aspecto de autonomia e assegurando a sua identidade institucional à medida que define consensualmente uma intencionalidade ético-política que deverá nortear as ações desenvolvidas, nos seus diferentes eixos institucionais, o administrativo, o financeiro e o pedagógico.

\section{Projeto político-pedagógico : um instrumento fundamental da promoção dos direitos humanos}

O projeto político pedagógico é um instrumento de trabalho que mostra o processo e o caminho percorrido para se chegar aos resultados. Ele valoriza a identidade da escola, e por isso deve ser aceito por todos os envolvidos e elaborado democraticamente. A abordagem do projeto político-pedagógico, como organização do trabalho de toda a escola, está fundada nos princípios que deverão nortear a escola democrática, pública e gratuita (VEIGA, 2004: 17-22): “igualdade de condições para o acesso e permanência na escola, o que requer uma ampliação do atendimento com simultânea manutenção da qualidade; qualidade que não pode ser privilégio de minorias econômicas e sociais e tem que ser tanto técnica quanto política, fundamental para a participação e consciência crítica; gestão democrática que abrange as dimensões pedagógica, administrativa e financeira, e visa romper com a separação entre o pensar e 
o fazer, entre teoria e prática, bem como a ampla participação dos representantes dos diferentes segmentos da escola nas decisões e ações administrativas e pedagógicas; liberdade para aprender, ensinar, pesquisar e divulgar a arte e o saber direcionados para uma intencionalidade definida coletivamente; valorização do magistério relacionada à formação inicial e continuada, às condições de trabalho, remuneração, que são elementos fundamentais. A importância de todos esses princípios está em garantir a operacionalização nas estruturas escolares, para que ocorra efetivamente na dinâmica interna da escola".

Acredito que a análise dos elementos constitutivos da organização do trabalho pedagógico trará contribuições relevantes para a construção do projeto. $\mathrm{O}$ projeto político-pedagógico apresenta alguns elementos básicos (VEIGA, 2004: 23): as finalidades da escola; a estrutura organizacional; o currículo; o tempo escolar; o processo de decisão; as relações de trabalho e a avaliação.

As finalidades da escola referem-se aos efeitos intencionalmente pretendidos e almejados: finalidade cultural, política, social, formação profissional e humanística. A escola deve assumir o trabalho de refletir sobre sua intencionalidade educativa, quais as finalidades precisam ser reforçadas, quais precisam ser relegadas, outras que poderão ser mais bem detalhadas.

A escola de uma maneira geral possui duas estruturas: a administrativa e a pedagógica. A primeira assegura a locação e gestão de recursos humanos, físicos e financeiros. A estrutura pedagógica organiza as funções educativas para que a escola atinja de forma eficaz e eficiente as suas finalidades e refere-se às questões de ensino e aprendizagem. Tem que romper com a conformidade às regras fixadas, com a obediência a leis e diretrizes emanadas do poder central e com a cisão entre os que pensam e os que executam.

O currículo é:

uma construção social do conhecimento, pressuposto a sistematização dos meios para que essa construção se efetive; é a transmissão dos conhecimentos historicamente produzidos $\mathrm{e}$ as formas de 
assimilá-los; portanto, produção, transmissão e assimilação são processos que compõem uma metodologia de construção coletiva do conhecimento escolar (VEIGA, 2004: 27).

Assim, podemos dizer que o currículo não é um instrumento neutro, ele passa uma ideologia, expressa uma cultura. Não pode ser separado do contexto social, uma vez que é socialmente situado e culturalmente determinado. Toda a gama de visões do mundo, as normas e valores dominantes são passados aos alunos no ambiente escolar, no material didático e na relação pedagógica.

O calendário escolar ordena o tempo: determina o início e o fim do ano, prevendo os dias letivos, as férias, os feriados, avaliação, as reuniões etc. Quanto mais compartimentado for o tempo, mais hierarquizadas serão as relações sociais, reduzindo também as possibilidades de se institucionalizar o "currículo-integração" que conduz a um ensino em extensão (VEIGA, 2004: 29).

O processo de decisão, geralmente, é orientado por procedimentos formalizados, prevalecendo as relações hierárquicas de mando e submissão, de poder autoritário e centralizador. Pelo contrário, deve prever mecanismos que estimulem a participação de todos no processo de decisão. Isso requer uma revisão das atribuições, da distribuição do poder e da descentralização do processo de decisão e uma instalação de mecanismos, como o processo de eleição, visando à participação de todos.

As relações de trabalho deverão estar calcadas nas atitudes de solidariedade, de reciprocidade e de participação coletiva. Deve propiciar a construção de novas formas de relações de trabalho, com espaços abertos à reflexão coletiva que favoreça o diálogo, a comunicação horizontal entre os diferentes segmentos e a descentralização do poder.

Por último, Veiga (2004: 31) cita o elemento da avaliação. Afirma que ela nos leva à reflexão, com base nos dados concretos sobre como a escola se organiza para colocar em ação seu projeto político-pedagógico. Imprime uma direção às ações dos educadores e dos educandos. 
O trabalho do projeto pedagógico necessário à sociedade democrática não é o de implementação passiva de diretrizes educacionais e a conseqüente preparação dos alunos para apenas executarem ordens. A escola tem o direito e o dever de organizar o trabalho pedagógico que contribua para a formação do cidadão.

É o projeto político-pedagógico que dá voz à escola e é a concretização de sua identidade, de suas racionalidades interna e externa e, conseqüentemente, de sua autonomia. A autonomia não é um valor absoluto e sim um valor que se define numa relação de interação social. Ela não impede que a escola obedeça a diretrizes gerais, já que é regida por leis comuns ao sistema.Cada escola tem uma realidade específica, e a autonomia deve atender a essas especificidades. É um exercício de democratização de um espaço público e coloca a escola na responsabilidade de prestar contas de suas atividades, além de permitir participação efetiva da comunidade, caracterizando sua categoria eminentemente burocrática. A autonomia da escola justifica-se no respeito à riqueza cultural, superação das desigualdades e abertura à participação (NEVES in VEIGA, 2004). Quando as escolas têm autonomia, elas são sujeitos ativos de sua própria história, e não meras executoras. Com autonomia, a escola encontra um ambiente mais favorável à educação.

A escola deve contribuir na construção da autonomia intelectual e moral dos sujeitos, tornando-os aptos para participar e criar, exercendo sua cidadania. O esforço pedagógico deverá recair, em primeira instância, na interpretação das práticas sociais da comunidade escolar, identificando as formas de sobrevivência, os valores, a organização, as crenças, o lazer, que determinam as representações e os saberes coletivamente construídos.

A autonomia não se resume em autonomia apenas financeira e administrativa, mas principalmente política, ou seja, o projeto político-pedagógico deve ser construído coletivamente, o que pressupõe todo um entendimento compartilhado sobre valores e normas entre todos os envolvidos no cotidiano da escola. Além disso, implica em um compromisso coletivo acerca dos objetivos e metas a serem alcançados dentro de uma prática de negociação e marcante horizontalidade nos processos de ação 
e reflexão.

Apesar de a expressão "projeto político-pedagógico" ter se tornado comum nos últimos anos, nem sempre tem conseguido superar a dicotomia entre as dimensões política e pedagógica. A tarefa de construção de um projeto políticopedagógico requer um longo processo de reflexão-ação (unidade teoria/prática) orientado por parâmetros que se articulam em duas dimensões.

O projeto político-pedagógico vai além de um simples agrupamento de planos de ensino e de atividades diversas. Ele é construído e vivenciado em todos os momentos, por todos os envolvidos com o processo educativo da escola. Por isso, como disse Veiga (2004: 14-15):

todo projeto político-pedagógico da escola é, também, um projeto político por estar intimamente articulado ao compromisso sociopolítico com os interesses reais e coletivos da população. É político no sentido de compromisso com a formação do cidadão para um tipo de sociedade. (...) $\mathrm{Na}$ dimensão pedagógica reside a possibilidade da efetivação da intencionalidade da escola, que é a formação do cidadão participativo, responsável, compromissado, crítico e criativo. É pedagógico no sentido de definir as ações educativas e as características necessárias às escolas para cumprir seus propósitos e sua intencionalidade.

Para Veiga (in VEIGA, 2004: 113), cabe ao projeto políticopedagógico os papéis de organizador da diversidade, construtor de espaços de autonomia, gerador da descentralização e impulsionador de uma atitude democrática e comunicativa. O projeto político-pedagógico não se concretiza sem que se leve em conta o dia-a-dia da escola, com as características socioculturais de seus participantes, e deve ser coletivo e autônomo.

A permanente construção democrática do projeto político-pedagógico deve ser uma prática efetiva, não apenas um meio de organização da instituição. "O projeto político-pedagógico como expressão operativa de uma intencionalidade éticopolítica e pedagógica compartilhada e assumida consensualmente por todos os sujeitos de ação envolvidos na práxis escolar, no exercício de sua soberania" (GARCIA in 
TORRES, 2001: 268).

A escola, dessa forma, deverá retomar sua função fundamental, além do papel do conhecimento, propiciar o conhecimento de inúmeras habilidades historicamente conhecidas por todos, como também oferecer ao seu corpo discente o desenvolvimento de habilidades para observação, interpretação, crítica e expressão, manuseio tecnológico, possibilitando a esse aluno tornar-se um agente de ação transformadora, capaz de fazer leitura do mundo que o cerca, posicionando-se politicamente.

Essa expectativa em relação à escola exige dos educadores uma vigilância permanente em relação a sua qualificação e atualização chamada formação continuada. O domínio de um corpo teórico, atualizado pela reflexão coletiva, poderá conferir aos professores autonomia de ação, criatividade, possibilidades de construção de instrumental didático, alternativas metodológicas, uma capacidade de gestão (VEIGA, 2004: 21).

A referida autora acrescenta que a formação continuada dos profissionais da escola comprometida com a construção do projeto político-pedagógico não deve se limitar aos conteúdos curriculares, mas se estender à discussão da escola de maneira geral e de suas relações com a sociedade. É um direito dos professores ter um aperfeiçoamento profissional para que seja valorizada toda a sua experiência pedagógica, possibilitando uma progressão funcional e qualificação.

Essa relação permanente e integrada entre educação, capital social e sustentabilidade forma o processo crítico do desenvolvimento social e, como todo processo, deve ser gerenciado com a melhor metodologia de qualidade. "A gestão está na base da construção do capital social, do desenvolvimento sustentável e da formação de lideranças. E o alicerce de toda essa estrutura está nas mentes e no coração dos professores" (JOHANNPETER, 2006).

Assim, a valorização e capacitação dos professores podem promover a 
real melhoria da educação. Para tanto é preciso que os atores envolvidos sejam qualificados para poderem participar conscientemente do processo de educação.

Segundo Marques (in VEIGA, 2004: 148-149), o projeto político pedagógico não é algo que surge do nada, mas conforma práticas e atitudes que se expressam como rede de significações. A aprendizagem escolar é aquela formalmente intencionada e sistemática em tempo e lugar próprios e com recursos adequados. A escola só realiza suas funções na prática em sala de aula, na qual os professores e alunos fazem-se sujeitos e atores de seu ensinar e aprender.

As discussões sobre a interdisciplinaridade e o aperfeiçoamento nas práticas de planejamento participativo, bem como a preocupação com a construção de projetos político-pedagógicos que confiram identidade e coerência às práticas escolares, são sintomas desta revolução que vem ocorrendo no modo de conceber o ensino, a organização curricular e as relações pedagógicas.

Para alcançarmos esse nível de mudança, é preciso se embasar em um planejamento participativo que funciona como um instrumento teórico-prático capaz de facilitar a convergência entre o refletir e o agir dos indivíduos, formando sujeitos com oportunidade de combinar experiência com reflexão. Esta prática está sendo organizada de modo a ser democrática, convidando à participação tanto da família, como da escola ou do bairro, usando como base a comunicação e o diálogo. Dessa forma, o planejamento participativo propõe e pode implementar intervenções coletivas sobre o social, refletidas e conscientes (FALKEMBACH apud VEIGA, 2004: 132).

Vê-se, portanto, que o projeto político-pedagógico da escola é um convite à reflexão sobre as finalidades da escola, assim como a explicitação de seu papel social e a definição de caminhos, formas operacionais e ações a serem empreendidas por todos os envolvidos com o processo educativo. Ele precisa ser concebido com base nas diferenças existentes entre professores, alunos, funcionários, direção, pais e comunidade. É, assim, fruto de reflexão e investigação. 


\section{Estudo de caso: a Escola Classe 304 Norte do DF}

Relatar a experiência do processo de construção de um projeto político-pedagógico não é uma tarefa fácil, uma vez que o relato é na maioria das vezes parcial e fragmentado, prejudicando a visão de totalidade e omitindo a riqueza das relações que envolvem o cotidiano escolar. No entanto, o propósito da pesquisa é mostrar o projeto político-pedagógico como uma construção possível e nesse sentido, torna-se pertinente narrar a prática que vem ocorrendo nesta escola pública do Plano Piloto e, em especial, como o grupo de educadores está empenhado nesse processo.

É importante salientar que os aspectos mais significativos que caracterizam a experiência aqui relatada incluem a identificação com a comunidade local, buscando alternativas que imprimem dimensão política à ação pedagógica, e o processo de abertura da escola, construindo parcerias que auxiliam na conquista de espaços para sua proposta.

A escola da 304 Norte foi inaugurada no dia 28 de abril de 1977. Nesse momento, foram criados a Associação de Pais e Mestres, o Centro Cívico e a Sala de Leitura Eça de Queiroz. No ano seguinte, a escola passou a atender também educandos de $1^{\mathrm{a}}$ a $6^{\mathrm{a}}$ séries do ensino fundamental. Criado no ano de 1995, o Conselho Escolar passou a fazer parte da gestão escolar.

Este período corresponde a um momento de participação ativa da comunidade e uma marca expressiva em sua trajetória histórica. O envolvimento de todos os segmentos no processo educativo tem contribuído para a reestruturação e avaliação da gestão escolar e promovidas conquistas nas áreas administrativa, física, financeira e pedagógica.

Pela observação participante e as entrevistas percebemos que a escola conta com um grupo de profissionais e familiares comprometidos em oferecer um ensino de qualidade e um ambiente onde o educando pode construir seu conhecimento com muita alegria, prazer, envolvimento e motivação. Neste sentido, a Escola Classe 
304 Norte destaca-se como um espaço privilegiado, visando promover a participação efetiva da comunidade escolar.

Nessa perspectiva, vários passos são dados para assegurar um ambiente favorável e fértil para o desenvolvimento integral do ser humano (Retrato Pedagógico, 2007: 4): oportunizar às crianças e a todos que nela convivem, o direito pleno do exercício da cidadania; um espaço para o diálogo e a reflexão, como instrumento de superação de conflitos; a criação e recriação do conhecimento; a aproximação entre conceitos abstratos e o cotidiano; o apoio dado a cada um na construção do desenvolvimento de suas potencialidades no processo educativo e o convívio com a diversidade.

Segundo o Retrato Pedagógico (2007: 6), o cotidiano é organizado da seguinte maneira: em relação ao horário das aulas, o período matutino é de 07:30 às 12:20h; e o vespertino de 13:30 às 18:20. A Escola Parque 303/4 Norte recebe os alunos uma vez por semana a disciplina Educação Física e Artes.

O uso do uniforme (Retrato Pedagógico, 2007: 6) na rede pública visa à identificação do aluno dentro e fora da escola, proporciona maior segurança para as crianças e facilita o reconhecimento deste pelo servidor da portaria e também é obrigatório em todas as atividades extraclasse: passeios, exposições, feiras etc. $\mathrm{O}$ uniforme diário compõe-se de uma camiseta padrão, bermuda, short, calça ou short-saia azul marinho, tênis ou sandália franciscana nas cores azul, preto, branco ou marrom.

Pelo Retrato Pedagógico (2007: 6) tem-se que a agenda escolar é personalizada e seu uso é diário. Além de auxiliar a organização pessoal do aluno, é o meio de comunicação mais rápido e eficiente entre a família e a escola. Solicita-se a assinatura diária após a leitura dos registros apresentados. Dessa forma, faz-se o melhor acompanhamento do aluno.

Em relação ao material escolar e objetos pessoais (Agenda Escolar, 2007: 8) o esquecimento de materiais e roupas na escola é muito freqüente. Nestes casos, a criança pode recorrer ao serviço de "Achados e Perdidos" do 
estabelecimento. O material utilizado pelos alunos deve ser identificado com nome, série e turma. A escola faz algumas recomendações especiais: os objetos de valor não devem ser trazidos e os alunos de $2^{\mathrm{a}}$ a $4^{\mathrm{a}}$ séries devem ter atenção especial quanto ao uso de livros do FNDE, pois eles serão emprestados e deverão ser devolvidos ao final do ano letivo.

Em casos de doenças (Agenda Escolar, 2007: 9), a escola só administrará remédios com a prévia orientação, por escrito, da família. A criança deverá ser atendida em sua residência com acompanhamento médico, preferencialmente. Em caso de ferimentos leves a família receberá comunicação imediata. Naqueles mais graves, ela será encaminhada para o hospital público mais próximo enquanto a secretaria da escola comunica o acidente aos pais.

A freqüência e a pontualidade (Agenda Escolar, 2007: 9) são avaliados da seguinte maneira: a falta de pontualidade prejudica o desenvolvimento escolar da criança e a escola deverá ser comunicada sobre a ausência do educando. Em caso de doença, o atestado deverá ser entregue à professora, para justificar a falta e não aboná-la. A freqüência no ano letivo deverá ser, no mínimo, de 75\%. Caso a criança tenha mais que 50 faltas $(25 \%)$, não será promovida para a série seguinte.

O uso dos telefones da escola (Retrato Pedagógico, 2007: 6) é restrito ao atendimento dos casos de urgência. Os pais deverão providenciar cartão telefônico para a criança, orientando-a sobre o uso correto do telefone público existente na escola (orelhão).

Além disso, a escola promove um trabalho de educação ambiental e valorização do bem público. Solicitam à família, portanto, o reforço das orientações dadas, educando seus (suas) filhos (as) para a utilização e manutenção, dos equipamentos e bens existentes no estabelecimento (Agenda Escolar, 2007: 9).

A família tem direito à orientação e acompanhamento escolar e toda equipe pedagógica tem horário especial para atendimento aos pais. Se necessário, este pode ser solicitado por meio da agenda dos filhos. Durante o ano, são realizadas 
atividades extraclasse onde a presença do educando é indispensável e, nessas ocasiões, é solicitado o comparecimento de todos, sendo obrigatória a autorização por escrito para a participação da criança.

\subsubsection{Perfil sócio-econômico e político-ideológico das docentes}

Esta parte da pesquisa apresentará os dados referentes ao perfil sócioeconômico das docentes (sexo, idade, estado civil, cor/raça, religião, escolaridade, renda familiar, local de moradia, tempo de serviço como professor, tempo de serviço na SEEDF e tempo de serviço na escola) e o perfil político ideológico das mesmas (participação em associação comunitária, movimento social e/ou entidade religiosa; filiação e tempo de filiação ao SINPRO/DF; exercício de militância política e filiação partidária).

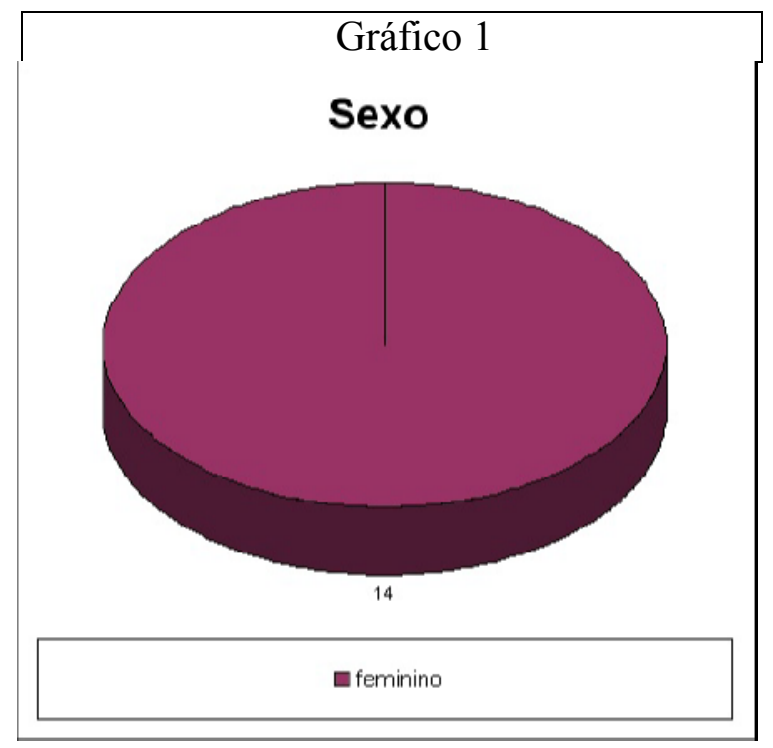

Podemos observar pelo primeiro conjunto de dados em relação ao sexo, que toda a equipe pedagógica e de professores da escola é composta por mulheres. Pode-se inferir desta predominância feminina na escola alguma influência tanto na perspectiva pedagógica adotada, quanto na presença de certos valores. 


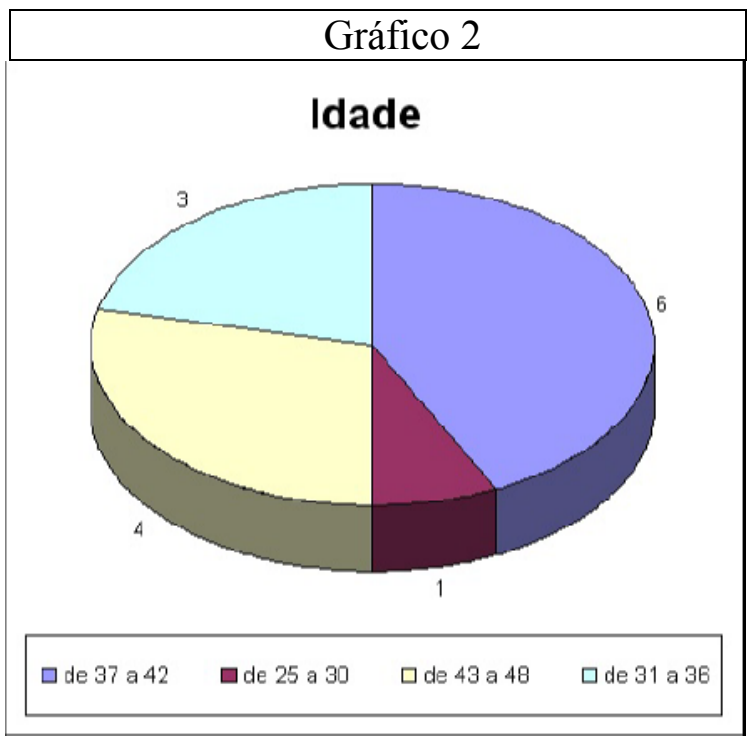

Quanto à idade das professoras, grande parte (10) situam-se na faixa de 37 a 48 anos, seguida por 3 informantes que se situam entre 31 e 36 anos. Neste sentido, podemos inferir que a maioria das docentes está em fase de vida adulta, o que demonstra um maior tempo de vida e possivelmente um convívio com maior número de experiências nas relações sociais.

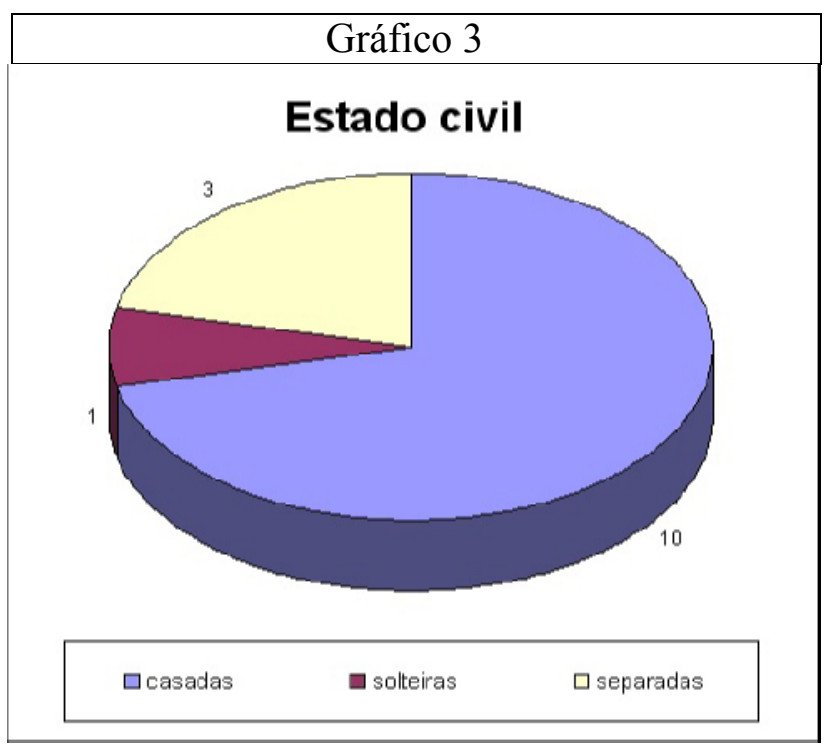

De acordo com o Gráfico 3, a maioria das professoras são casadas (10), sendo 3 separadas e apenas 1 é solteira. Esta informação é reforçada pelo 
gráfico anterior, no sentido de que a experiência de vida adulta pode ser um elemento positivo para o exercício da docência junto a crianças pequenas, em função das experiências vividas e do convívio familiar.

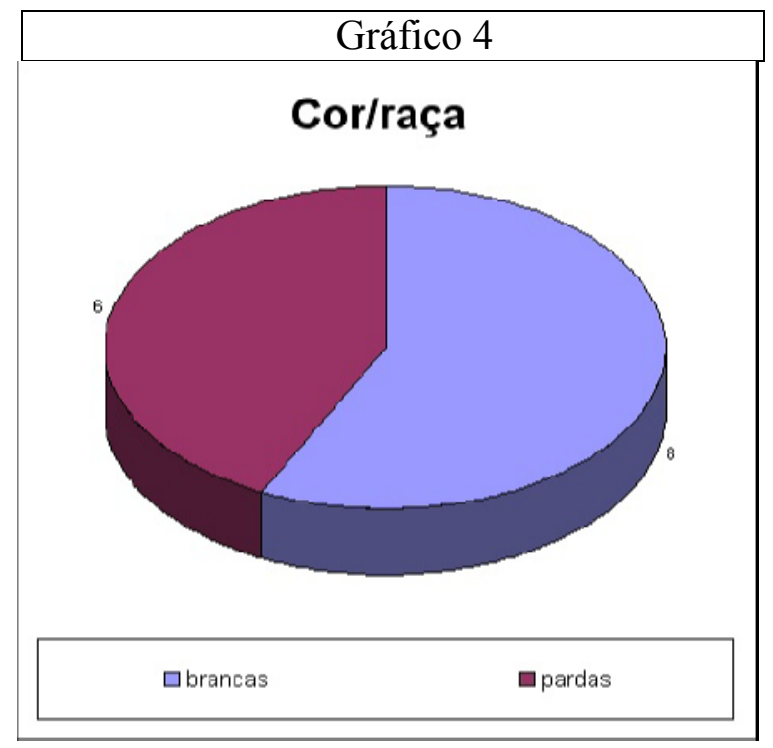

Quanto à cor, as informantes ficaram praticamente divididas em duas categorias: 8 brancas e 6 pardas. Este dado é interessante, pois aponta no sentido que, ainda hoje, um número expressivo de docentes é classificado como branco. O perfil de estratificação social do país parece apoiar esta situação específica, uma vez que os indivíduos de cor branca são aqueles que têm melhores posições na escala social. No caso desta escola classe, isso se reflete no posicionamento da hierarquia interna, pois as professoras estão executando trabalho intelectual, que exige maior formação acadêmica e não exercendo tarefas manuais. 


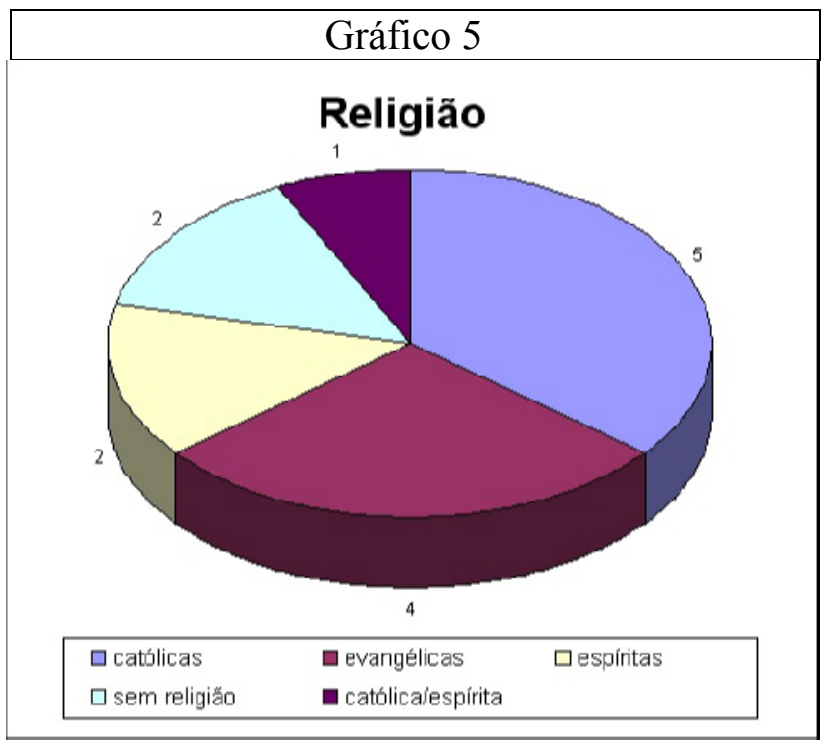

De acordo com o Gráfico 5, a maioria das docentes (12) possuem alguma filiação religiosa: 5 são católicas, 4 evangélicas, 2 espíritas, 2 sem religião e 1 que se classificou como praticante do catolicismo e espiritismo.

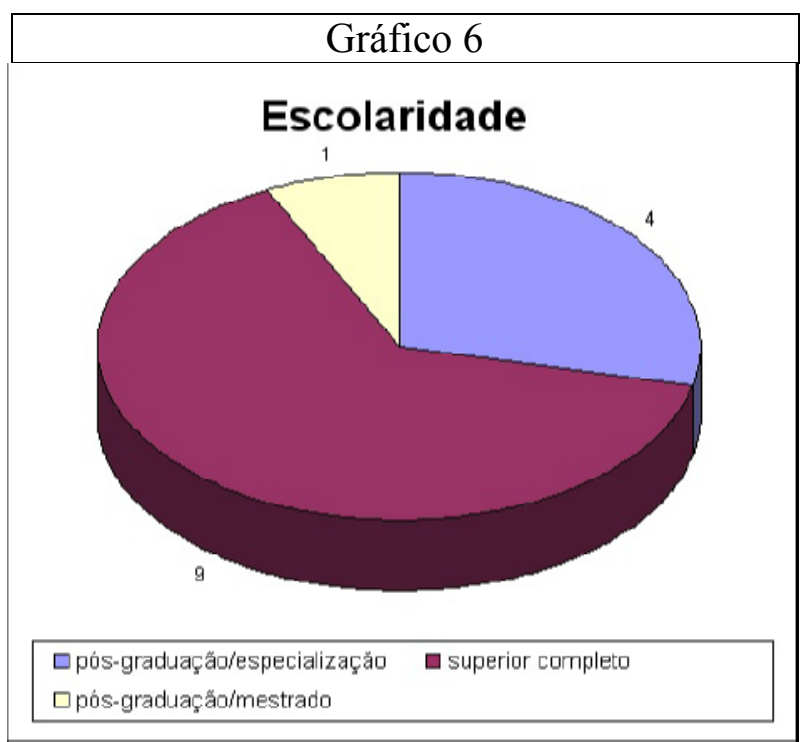

Um outro conjunto de dados colhidos foi em relação à escolaridade: 9 professoras possuem o nível superior completo, e 5 tem algum tipo de especialização. Isso revela uma preocupação com a formação continuada, fundamental para a 
transmissão de maiores conhecimentos e experiências que a academia proporciona, além de possibilitar uma ascensão profissional e melhores salários.

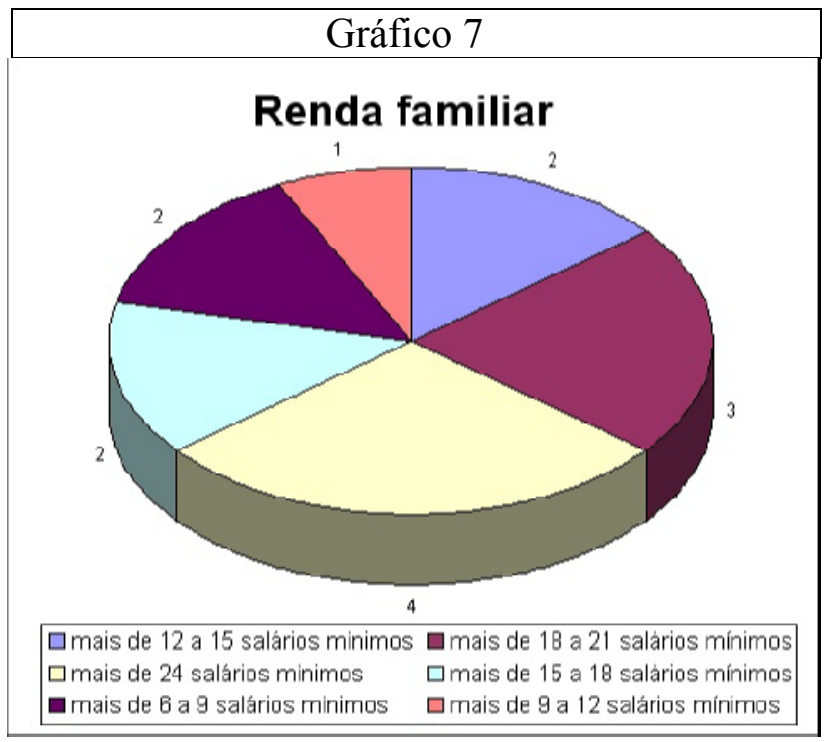

Podemos observar pelo Gráfico 7 que 4 professoras têm renda familiar de mais de 24 salários mínimos, o que equivale a uma quantia superior a $\mathrm{R} \$$ 9.120,00; 3 estão na faixa entre mais de 15 a 18 salários (mais de $\mathrm{R} \$ 5.700,00$ a $\mathrm{R} \$$ 6.840,00); 2 estão situadas em renda de mais de 18 a 21(mais de R\$ 6.840,00 a R\$ 7.980,00); 2 na faixa de mais de 12 a 15 salários (entre mais de $\mathrm{R} \$ 4.560,00$ a $\mathrm{R} \$$ 5.700,00); 2 no estrato de mais de 6 a 9 (entre mais de $\mathrm{R} \$ 2.280,00$ a $\mathrm{R} \$ 3.420,00$ ) e 1 mais de 9 a 12 salários mínimos (entre mais de R\$3.420,00 a R \$ 4.560,00).

Esse conjunto de informações permite inferir que as professoras desta escola estão inseridas no estrato social de classe média, o que de certa maneira favorece as condições básicas para o exercício da profissão. 


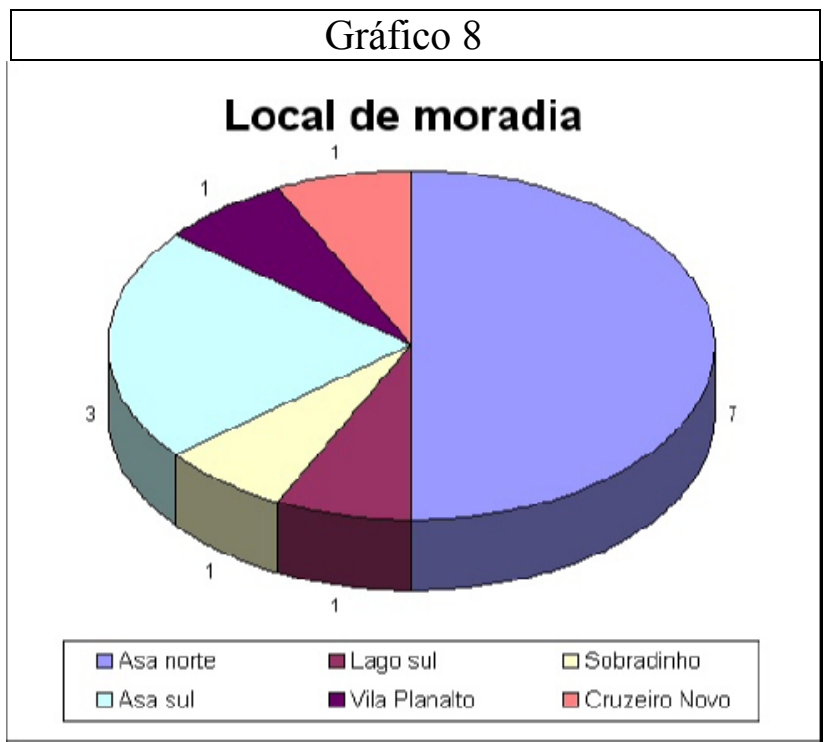

Do total das docentes, a metade (7) reside na Asa Norte, o mesmo bairro da escola, o que facilita o acesso ao local de trabalho. Quanto às demais, 3 moram na Asa Sul, 1 no Lago Sul, 1 em Vila Planalto, 1 em Sobradinho e 1 no Cruzeiro Novo. Com exceção das professoras residentes em cidades satélites e no Lago Sul (3), todas as demais têm o local de moradia próximo à escola.

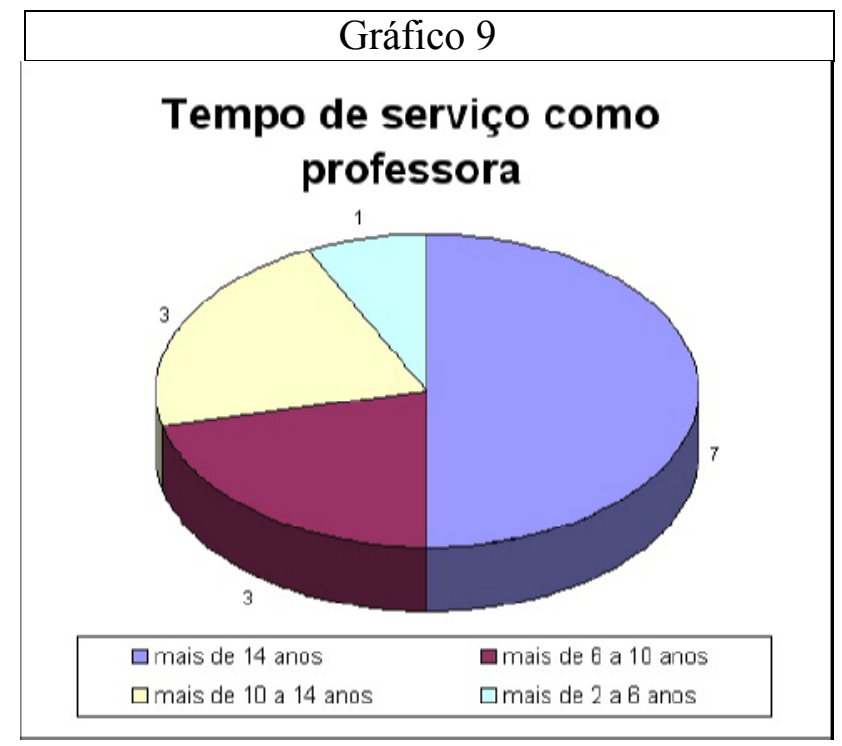

Interessante observar no Gráfico 9 que 50\% das docentes tem mais de 
14 anos no exercício da profissão, enquanto a outra metade está dividida entre mais de 10 a 14 anos e mais de 6 a 10 anos, e apenas 1 situa-se entre mais de 2 a 6 anos. Esses dados revelam que a maior parte das professoras tem longa experiência no ofício, o que pode se refletir na competência para o exercício do ensino.

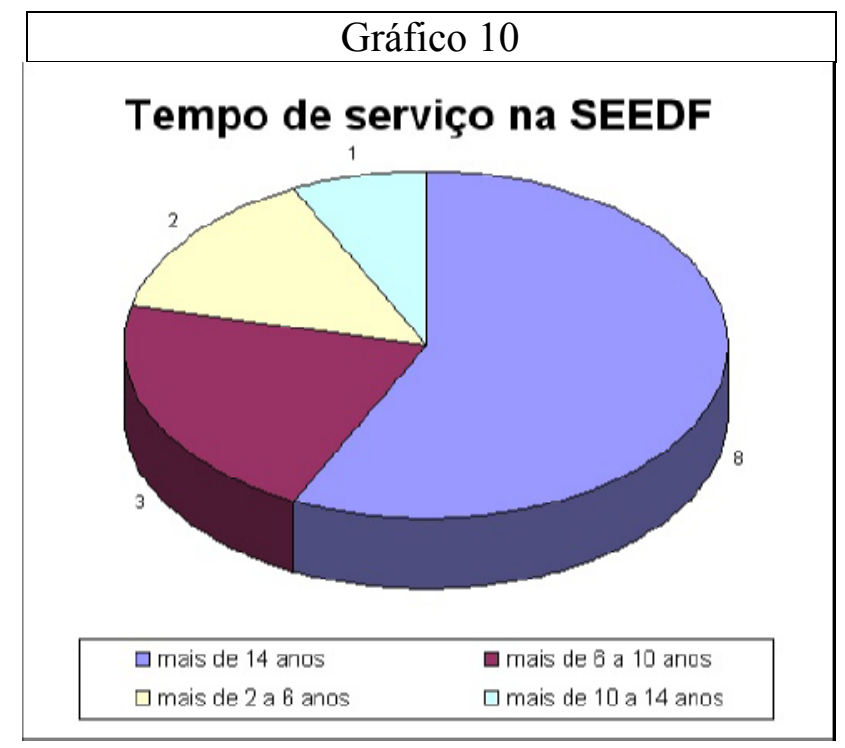

As informações do Gráfico 10 mostram que pouco mais da metade das docentes tem mais de 14 anos na SEEDF, enquanto 3 situam-se entre mais de 6 a 10, 2 na faixa de mais de 2 a 6 e 1 professora entre mais de 10 a 14 anos. De acordo com esses dados, verificamos que a maior parte das docentes tem um tempo de serviço na SEEDF igual ou relativamente próximo ao tempo de serviço como professora. 


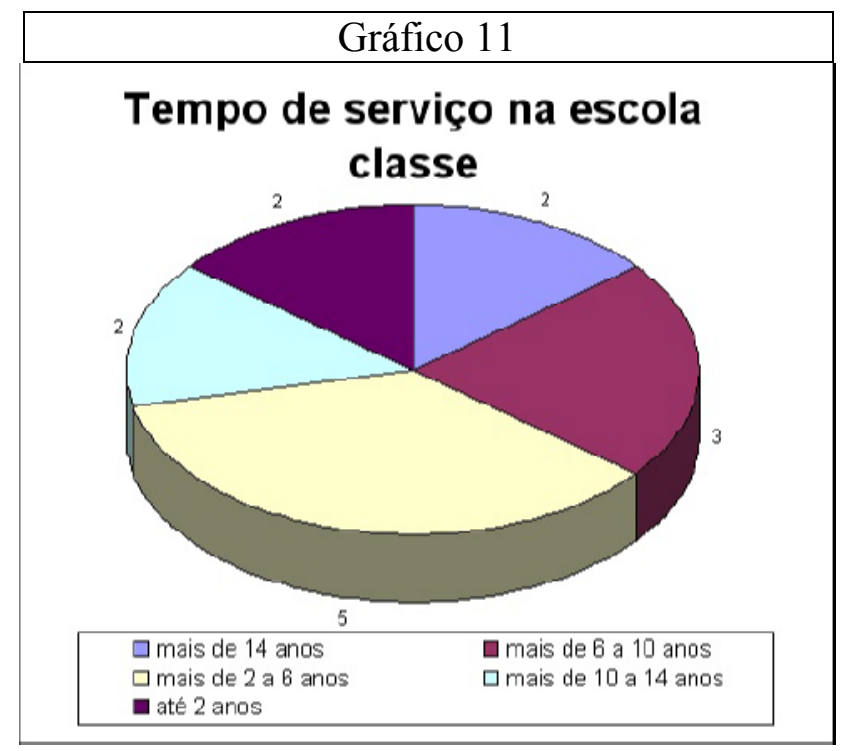

A metade das professoras está situada, de acordo com o Gráfico 11, entre mais de 6 a mais de 14 anos na escola, o que significa uma grande estabilidade do corpo docente, fator fundamental para garantir a continuidade do projeto políticopedagógico da escola. A outra metade das professoras está distribuída em até 6 anos de exercício docente nessa unidade escolar.

Este tempo expressivo de convivência na escola por parte da metade das professoras é uma experiência muito importante para o cotidiano da escola e para amadurecer a relação com as crianças e outros profissionais dentro da proposta de transmissão dos conhecimentos e da prática de resolução de conflitos. 


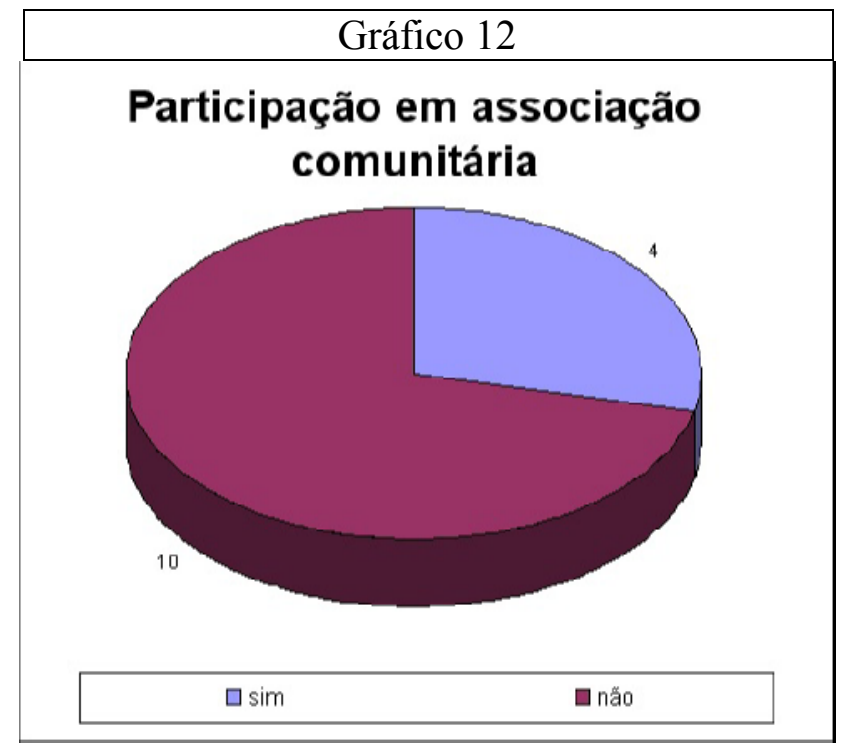

Interessante verificar no Gráfico 12 a experiência de não participação em associação comunitária por parte da maioria (10). Este dado se soma ao Gráfico 13 onde o mesmo número de informantes afirma que também não participou de nenhum movimento social.

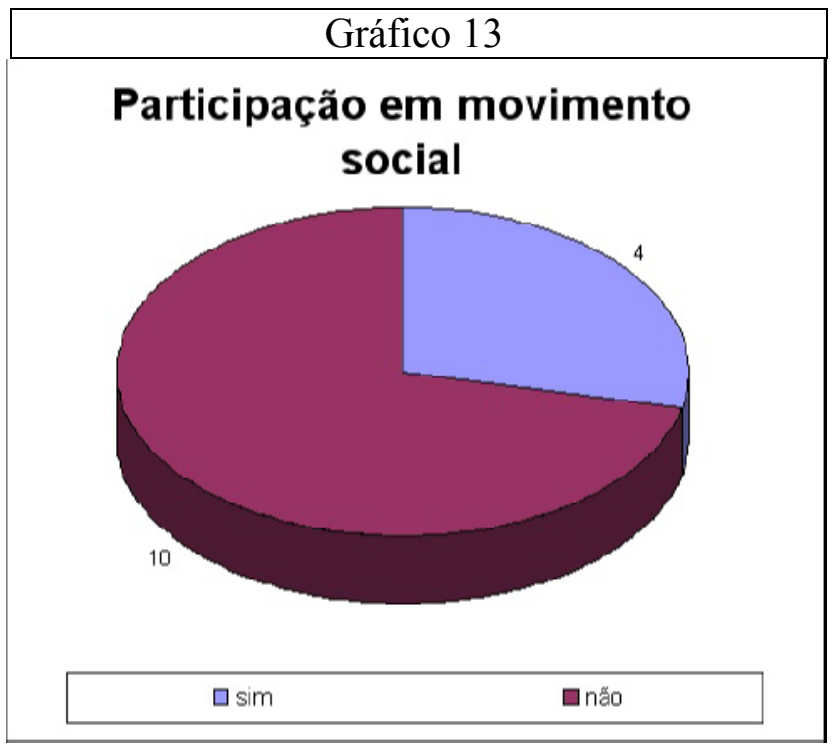

As informantes que participam de movimentos sociais ou associações comunitárias (4) tem como motivo uma razão de parentesco com algum membro dessas 
organizações sociais, ou interesses pessoais, e apenas 4 citaram a importância de poder ser ouvida, dar opinião e participar do movimento. Isso demonstra uma posição mais passiva em relação à política, revelando que as professoras têm pouca vivência das lutas da sociedade civil.

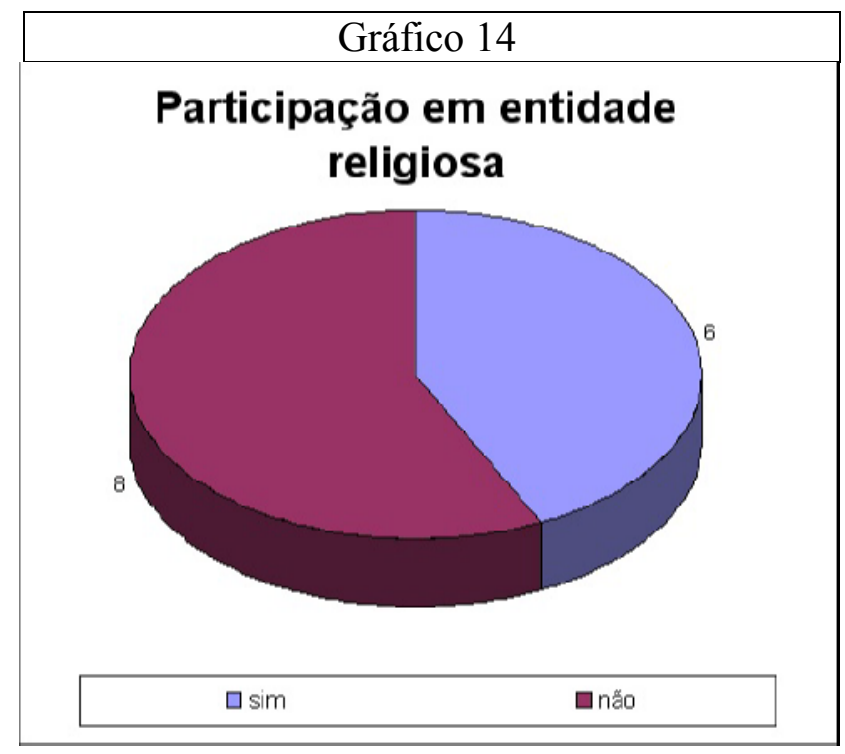

O Gráfico 14 revela que apenas 6 professoras participam de alguma entidade religiosa, sendo que, como demonstra o Gráfico 5, todas as docentes declararam ter alguma religião. Neste caso, cabe destacar o perfil pouco participativo deste segmento profissional, pois mesmo na instância religiosa não houve presença ativa. 


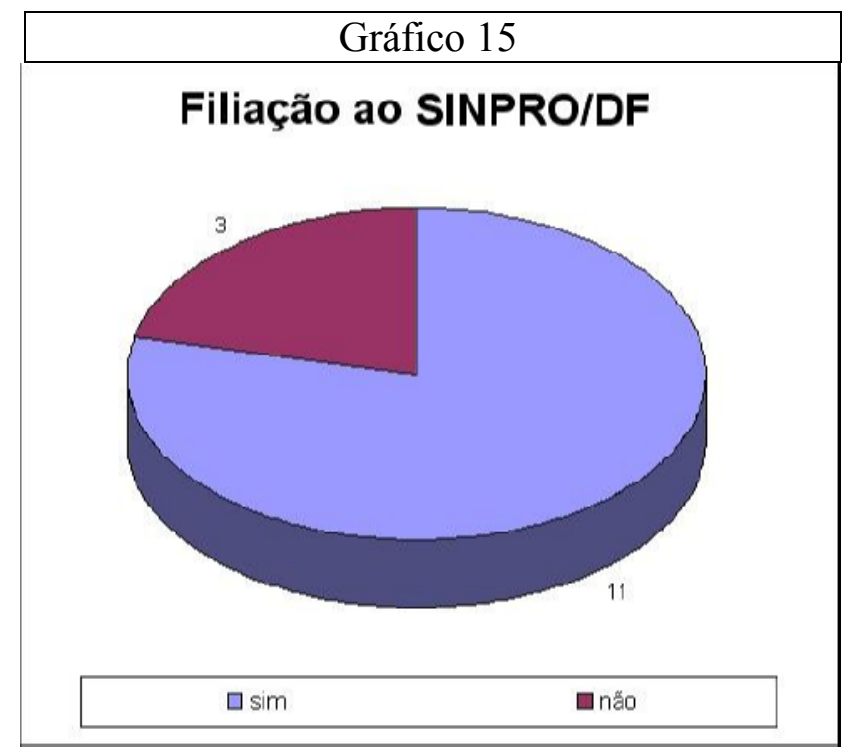

A grande maioria das docentes (11) está filiada ao SINPRO/DF. Os motivos da filiação estão relacionados à representatividade da entidade e à garantia de direitos conquistados, além do papel sindical de fiscalização e combate aos abusos cometidos pelos empregadores.

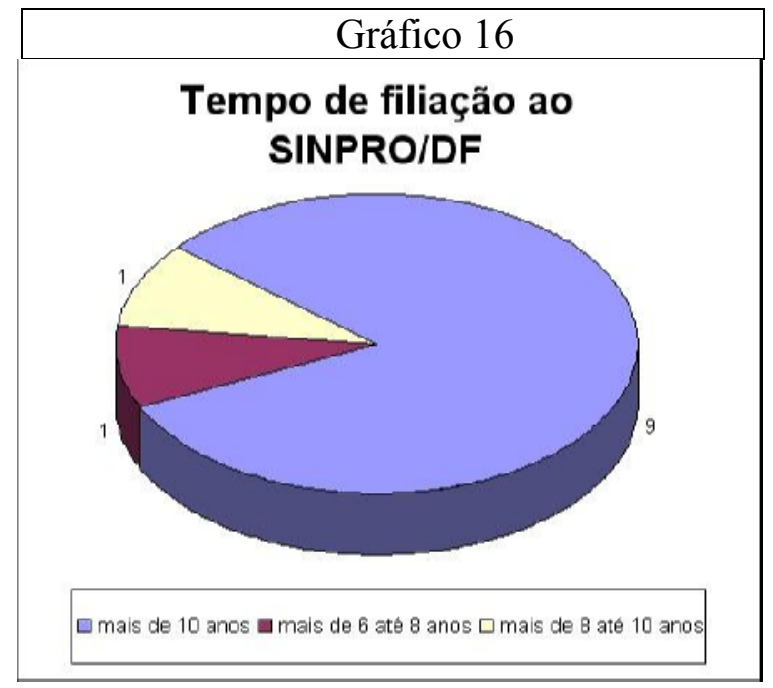

Apesar da maioria das professoras serem filiadas ao sindicato há mais de 10 anos, conforme demonstra o Gráfico 16, nenhuma das entrevistadas ocupou cargo no SINPRO/DF. Esta questão está relacionada ao fato do sindicato até hoje ser um 
reduto masculino, onde a esfera de poder é bastante controlada por membros desse grupo.

Em relação às greves realizadas pelo sindicato desde os anos 1980, as entrevistadas afirmaram que houve melhora dos salários, ganharam gratificações, licenças, além do plano de carreira e jornada ampliada de trabalho.

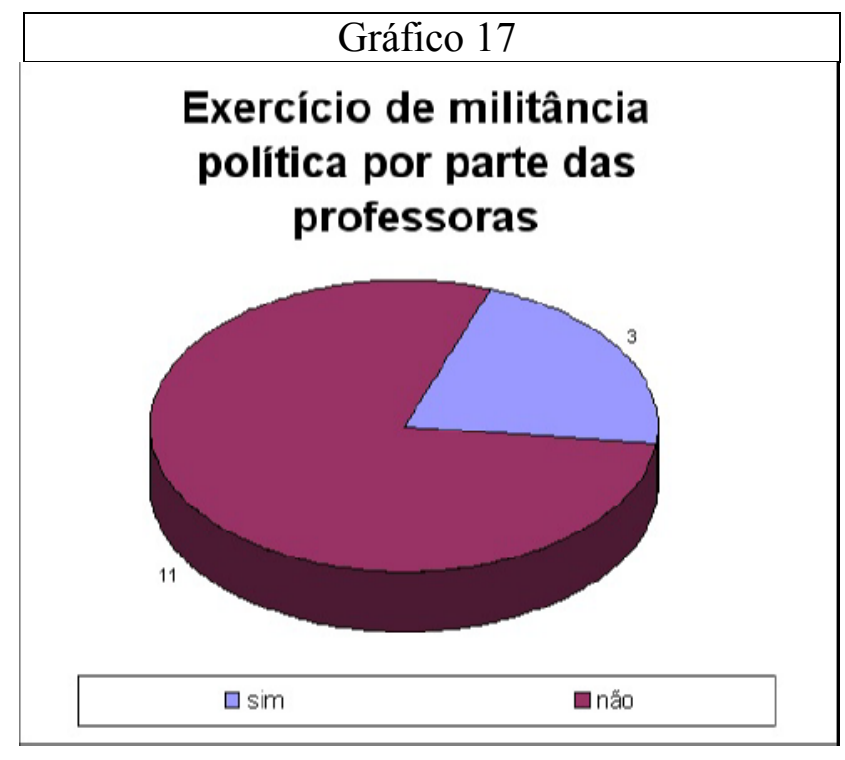

O Gráfico 17 revela que a grande maioria das docentes não é militante, ainda que 3 admitiram participar de algum partido. Este dado demonstra de certa maneira, o desinteresse das professoras pela esfera da política. 


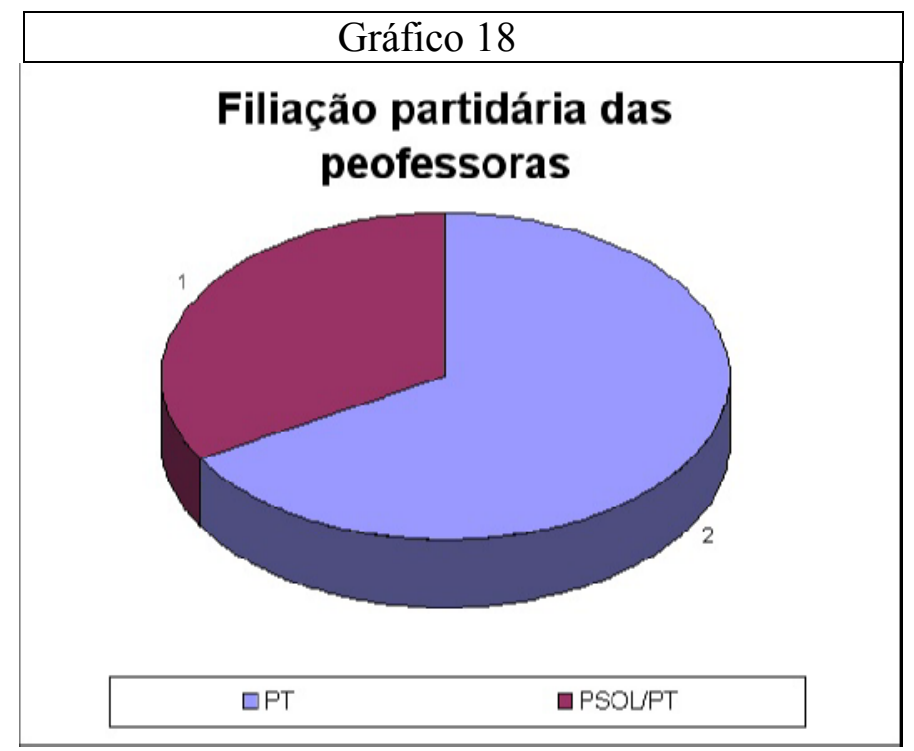

Nenhuma das professoras é filiada a algum partido político e apenas 3 admitiram ser militantes: 2 do PT e 1 do PSOL e PT. Este dado confirma o distanciamento das docentes em relação ao mundo da política.

\subsubsection{Escola e comunidade}

A relação da escola com a comunidade foi registrada pela grande maioria das docentes como uma parceria com a sociedade civil, uma vez que a comunidade escolar participa muito, tem enfrentado muitos conflitos na escola, porque está organizada, ajuda a lutar pelas causas que desde o início do ano estão sendo enfrentadas e ainda é a responsável pelas conquistas que a escola já tem. Enfrentou este ano a retirada da sala de leitura para transformar em sala de aula, as estratégias de matrícula, além da situação dos alunos que necessitam de apoio escolar especial e precisam de turmas reduzidas. Um ponto de apoio importante são os sindicatos, sempre que a escola solicita, os dirigentes vem para esclarecer dúvidas. 


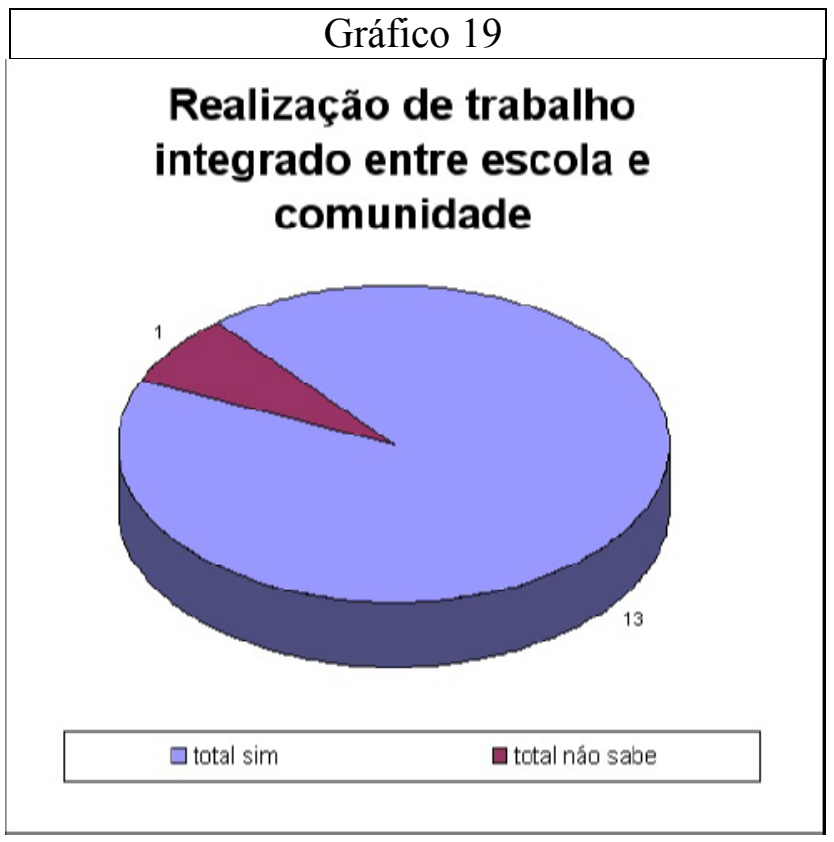

De acordo com o gráfico acima, a maioria absoluta das informantes (13) tem informações sobre o trabalho existente entre a escola e a comunidade.

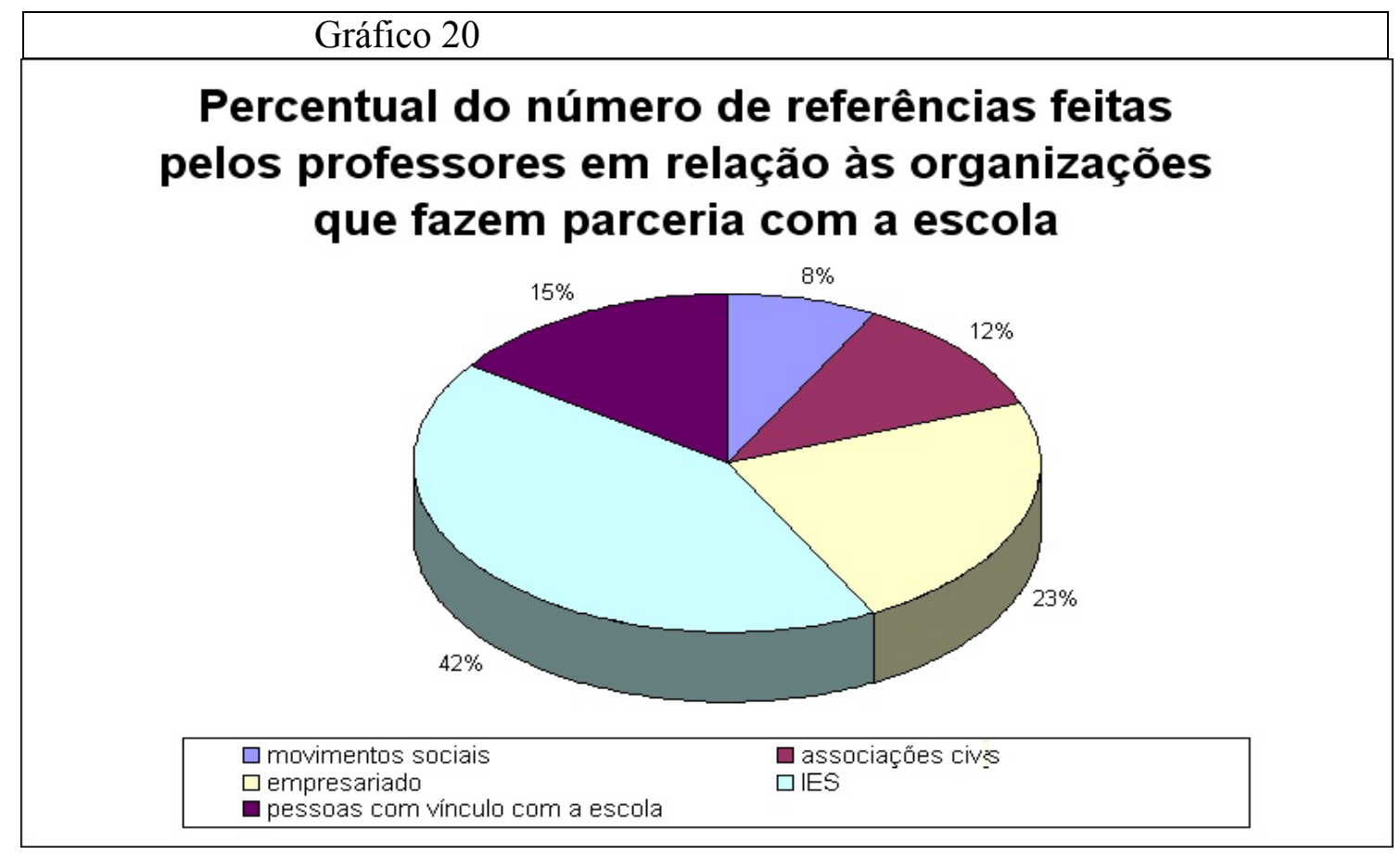


As informações contidas no Gráfico 20, a maior parceria da Escola Classe 304 Norte é com instituições de nível superior (42\%), seguido pelo apoio dado pelo empresariado (23\%) e por pessoas que tem vínculo com a escola (15\%) os quais somam-se um total de $80 \%$ do total das parcerias. Em menor escala está as associações civis $(12 \%)$ e os movimentos sociais $(8 \%)$.

A parceria com a UnB, é realizada por meio do projeto do professor Cristiano sobre o aprendizado da matemática no $4^{\circ}$ ano. Ele faz o acompanhamento na sala de aula com professores e alunos quinzenalmente, observa e orienta as aulas. Ele trabalha com crianças com mais dificuldades e utiliza jogos de matemática. No ano passado, também teve um curso de introdução à música ministrado por alunos do Departamento de Música da UnB que ensinaram flauta para crianças. Com o empresariado, foi feita parceria na área de educação ambiental, por meio da reciclagem de papel e lixo, além de plantação.

De acordo com as informações dadas pelo grupo focal realizado com os pais, pode ser observado que a escola possui características favorecedoras da participação dos pais.Estes últimos costumam ser bem recebidos no ambiente escolar, o que segundo eles, já facilita bastante.

A apreciação a respeito da participação dos pais na escola pode ser conhecida pelos discursos abaixo:

"Escola de boa qualidade é inseparável da participação" (Pedro).

“Os pais se sentem incomodados a participar, no bom sentido"(Joana).

Outros depoimentos afirmam que são sempre chamados, bem como a comunidade, a participar de tudo o que se passa no ambiente escolar, ou seja, há uma construção coletiva. Os pais têm abertura para ir à direção fazer reclamações e existe muita discussão com as gestoras. Há uma interação muito grande e as divergências de opinião são vistas como algo que fortalece a gestão da escola. 
"Meu filho encontrou espaço na escola para ser diferente" (Daniel).

“(...) o diferencial é que não se preocupa com a educação em si, a matéria, mas em passar valores para alunos (...) (Me sinto) privilegiada em estar numa escola inclusiva" (Kátia).

“(...) o diferencial é vivenciar. Ensinar não é só passar conhecimento. Aqui ensinam direitos humanos nas pequenas práticas" (Rafael).

Toda a estrutura organizacional da escola é formada de modo a confirmar e possibilitar a participação dos pais e dos alunos. Ela inclui o Conselho Escolar e o Conselho de Classe, além de instituições auxiliares, tal como a Associação de Pais e Mestres (APM). Isso demonstra as iniciativas de democratização dos processos de decisão internos da escola. Na realidade, os professores fazem tudo para que os pais e a comunidade não ofereçam ajuda apenas financeira e material, mas também participem do processo de ensino-aprendizagem e das decisões tomadas na escola.

Os educadores e educandos percebem a escola como um local de trabalho e estudo, além de ser um lugar para realizar suas atividades e interesses.Dessa maneira, a escola se transforma em um local de formação e de preparação para o trabalho e exercício da cidadania.

Para concretizar o projeto político-pedagógico é necessário, segundo Veiga (2005: 115), criar órgãos de gestão que garantam por um lado, a representatividade e, por outro, a continuidade e a legitimidade. Dentre esses órgãos, o Conselho Escolar é concebido como "local de debate e tomada de decisões". É um gerador de descentralização, órgão máximo de decisão no interior da escola.

O Conselho de Classe, acrescenta Veiga (2005:117) é "uma instância colegiada que possibilita a articulação entre os diversos segmentos da escola e tem por objeto o estudo do processo de ensino e suas relações com a avaliação da 
aprendizagem".

A Associação de Pais e Mestres é "uma instituição auxiliar que tem como finalidade colaborar no aprimoramento da educação e na integração famíliaescola-comunidade”. Exerce a função de sustentadora jurídica das verbas públicas recebidas e aplicadas pela escola, com a participação dos pais no seu cotidiano em cumplicidade com a administração (VEIGA, 2005: 118).

A participação da comunidade é um aspecto fundamental para o funcionamento da escola e a qualidade de ensino. Os pais são convidados para reuniões, discussões, tomadas de decisões, além de estarem presentes nas festas, na APM e no Conselho de Classe. Tem igualmente voz ativa em todas as decisões e atividades na escola. Todos os entrevistados disseram que os pais participam das atividades da escola e esta incentiva a participação dos mesmos, através de meios de comunicação tais como bilhetes, circulares e blogs.

Nesta escola, o Conselho Escolar é participativo, as crianças participam, a orientadora entra em sala de aula para conversar, discutir os problemas da turma. Além disso, tem debate com as professoras, a respeito da avaliação que os alunos fizeram do processo ensino -aprendizagem e das vivências pessoais na escola. Esta é uma ocasião especial, na qual os alunos têm total liberdade para dizer sobre o que gostam e assumir responsabilidades.

\subsubsection{Escola, democracia e cidadania}

No que se refere à escola e sua relação com a democracia e cidadania, todos os entrevistados alegaram lutar por seus direitos (mesmo os que não tem total certeza sobre seus direitos) e afirmaram que a Escola Classe 304 Norte realiza práticas democráticas e está comprometida com a formação de cidadãos. Isso demonstra que na prática diária, a escola busca exercer práticas democráticas. 


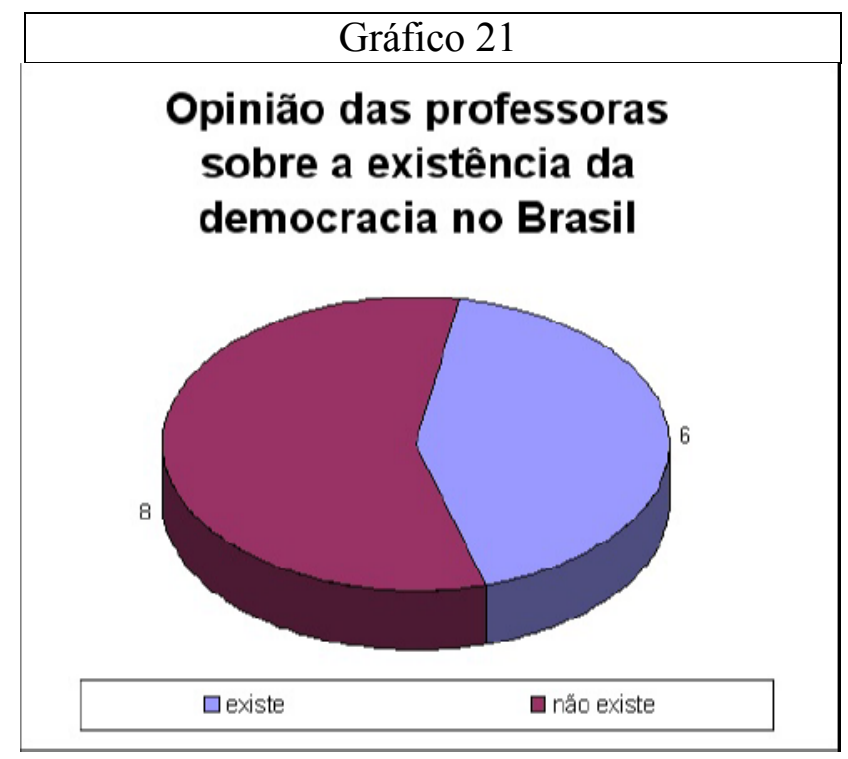

Interessante observar que apesar das entrevistadas confirmarem a existência de democracia na escola, elas estão divididas em relação à existência desta no Brasil. Pouco mais de 50\% (8) admitem não haver democracia no país, enquanto pouco menos de 50\% (6) afirmam existir. Cabe ressaltar que aquelas informantes que desconhecem haver democracia no país (8), afirmam que há muitas garantias e direitos previstos na legislação, mas o governo não cumpre, motivo pelo qual reconhecem que deveriam lutar mais para essa efetivação.

A maioria conhece seus direitos de cidadão (13) como, por exemplo, direito à família, educação, moradia, participação cultural, salário digno que me possibilite isso, saúde, alimentação, transporte, liberdade de expressão, pensamento, ir e vir, segurança, lazer, políticos de voto e eleição. Mas dizem não acreditar que no Brasil exista democracia (8), em função de se ter muitas garantias e direitos previstos na legislação, mas não há um cumprimento por parte do governo, reconhecem que deveriam lutar mais para essa efetivação. 


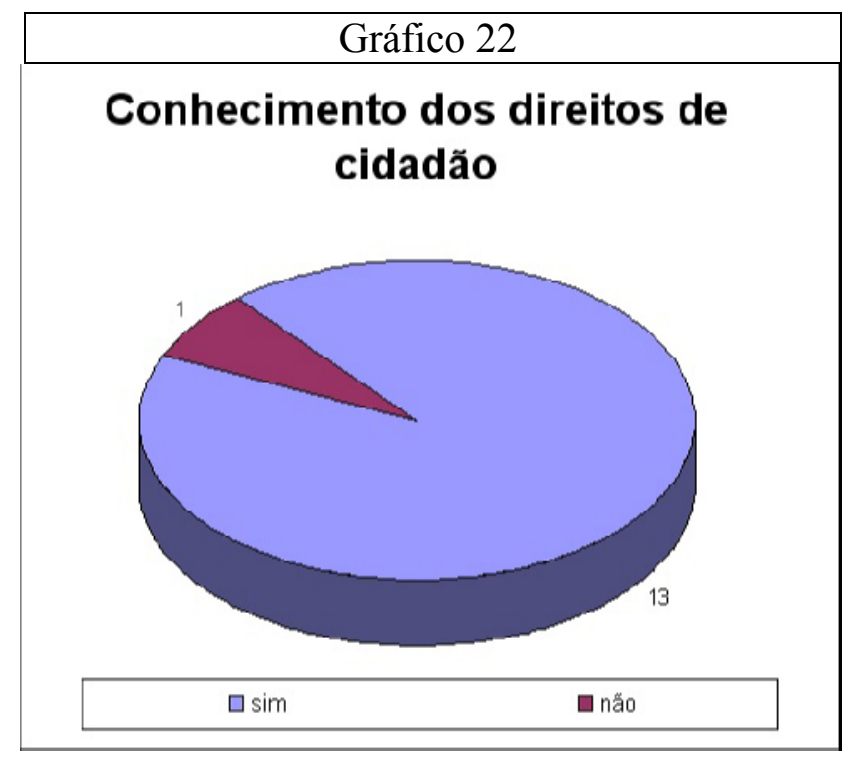

As entrevistadas relacionam o conceito de cidadão com o respeito aos seus direitos e cumprimento dos deveres, além de ter voz, participar e ser ouvido. Os direitos humanos foram relacionados a tudo aquilo que as fazem ser pessoas respeitadas socialmente, culturalmente, economicamente e na sua diversidade, o que as protegem enquanto pessoa humana numa visão mais global. Apontam como direito fundamental: qualidade de vida, saúde, direito de se colocar no mundo como pessoa e ser respeitado, direito de falar, pensar e de se expressar.

A escola segue alguns princípios epistemológicos ao adotar uma linha pedagógica que considera o conhecimento como resultado da interação entre o aluno que busca conhecer e aquilo que será conhecido (conceitos, idéias, definições). De acordo com essa perspectiva, o aluno torna-se construtor do seu próprio conhecimento, tendo o professor como mediador, orientador e incentivador desse processo, e o conhecimento é um meio para o seu desenvolvimento, tendo em vista certos objetivos a serem alcançados.

Em relação aos princípios didático-pedagógicos, a escola se funda em teorias que trazem uma nova visão no que se refere à relação existente entre o conhecimento, o aluno e o professor. Essa relação é integrada, construtiva e 
compartilhada, e tem por finalidade atender às necessidades e expectativas dos alunos, bem como às questões que tenham ressonância no seu cotidiano e às demandas sociais pertinentes ao seu meio.

Os princípios éticos-políticos, de acordo com o projeto políticopedagógico da escola, proclamam não ser esta responsável apenas pelo desenvolvimento de habilidades cognitivas, básicas em qualquer aprendizagem, mas também pela educação moral e ética de seus alunos. Nesse sentido, a escola tem oferecido uma educação que privilegia o desenvolvimento sistemático de competências cognitivas e de uma formação humana voltada para a construção de valores, destacando-se entre eles, a humildade, a solidariedade, o compromisso, o respeito, a liberdade, a cooperação e a democracia.

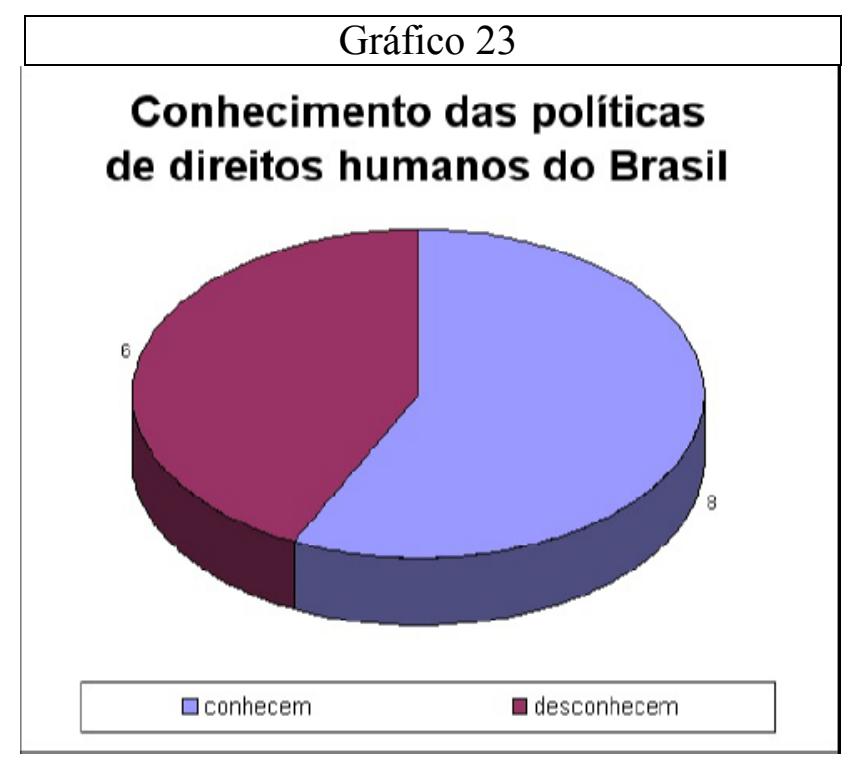




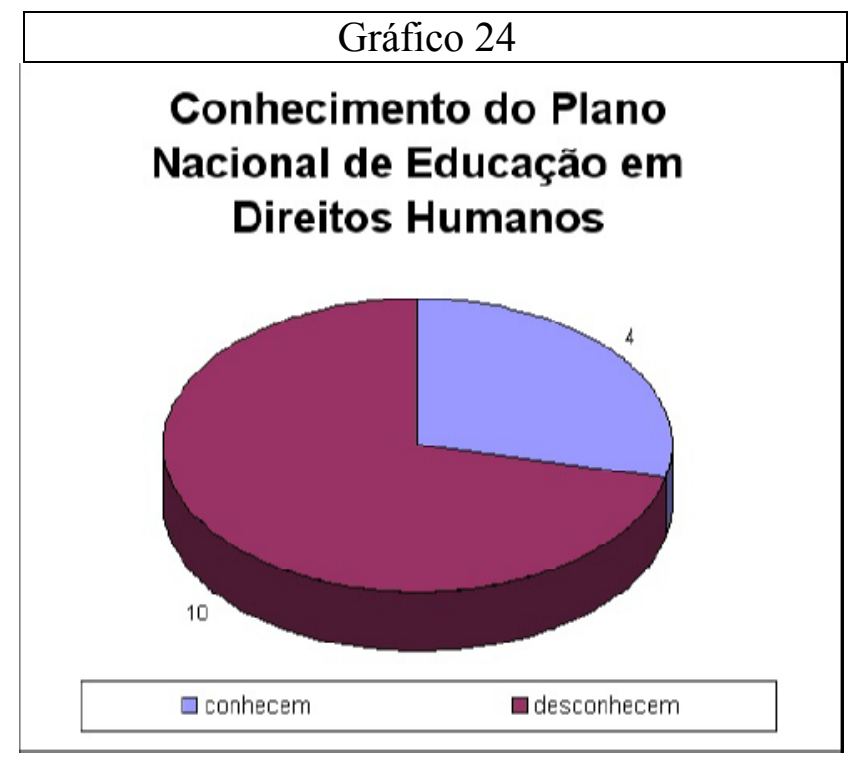

Apesar da maioria não conhecerem as políticas de direitos humanos do país e o Plano Nacional de Educação em Direitos Humanos lançado em 2003, a escola é inspirada nos princípios de democracia e nos ideais de solidariedade humana; tem por finalidade oferecer ensino de qualidade; oportuniza a todos a participação em atividades coletivas, onde o convívio com as diferenças proporciona o exercício do respeito mútuo; realiza suas atribuições com responsabilidade e compromisso; utiliza o diálogo para a superação de conflitos; inclui a formação ética, o desenvolvimento da autonomia intelectual, a criatividade e o pensamento reflexivo e crítico e valoriza a amizade através da criação de um espaço de harmonia e de prazer no ambiente escolar.

A escola procura educar baseando suas ações nos quatro pilares da educação: aprender a conhecer, a fazer, a conviver e a ser. O primeiro, no sentido de combinar uma cultura geral com a possibilidade de trabalhar em profundidade um pequeno número de matérias; significa também aprender a aprender, para se beneficiar das oportunidades oferecidas pela educação ao longo de toda a vida. O segundo, diz respeito à uma qualificação profissional, mas, de uma maneira mais ampla, envolve as competências que tornem a pessoa apta a enfrentar numerosas situações e a trabalhar em equipe. $\mathrm{O}$ terceiro, respeita o pluralismo, gerindo conflitos e vivendo em paz, e o 
último, implica que a educação deve contribuir para o desenvolvimento total da pessoa, no sentido da elaboração de pensamento autônomo e crítico para formular juízos de valores.

As informantes citam exemplos de democracia praticados pela escola, tais como: as decisões não são de cima para baixo; participam pais, professores e alunos, permitindo assim o exercício da cidadania constante; a comunidade escolar dá palpite, analisa projetos, os alunos dizem quais projetos querem fazer. Para as entrevistadas, o objetivo da escola é formar cidadãos, cientes dos seus direitos, a escola não se limita apenas a ensinar o conteúdo, mas a exercitar a cidadania, a crítica e incentivar as crianças a dar opinião, fazer entender que tem direitos, deveres e aprender a trabalhar com a diversidade e o respeito às diferenças.

As crianças têm momentos em que tem direito de voto nas atividades em sala de aula, no nome da turma, nas atividades, no que querem aprender ao longo do ano e nos projetos da escola. Combinam tudo, mostram e constroem regras juntos. Assim, as crianças opinam, votam, escolhem e tem um horário no pátio, no qual os professores sentam juntos e revêem tudo o que acontece na realidade escolar, resolvem conflitos, fazem combinados e planejamentos.

\subsubsection{Escola e educação em direitos humanos}

Quais seriam os pontos principais do conteúdo da educação em direitos humanos? Há um conteúdo que decorre da própria definição de direitos humanos e do conhecimento sobre as gerações ou dimensões históricas, sobre as possibilidades de reivindicação e de garantias etc. Este conteúdo deve estar efetivamente vinculado a uma noção de direitos, mas também de deveres, estes decorrentes das obrigações do cidadão e de seu compromisso com a solidariedade. É importante, ainda, que sejam mostradas as razões e as conseqüências da obediência a normas e regras de convivência. Em seguida, este conteúdo deve conter a discussão para a vivência - dos grandes valores da ética republicana e da ética democrática. Os valores da ética republicana incluem o respeito às leis legitimamente elaboradas, a prioridade do bem público acima dos interesses pessoais ou grupais, e a noção da 
responsabilidade, ou seja, de prestação de contas de nossos atos como cidadãos. Por sua vez, os valores democráticos estão profundamente vinculados ao conjunto dos direitos humanos, os quais se resumem no valor da igualdade, da liberdade e da solidariedade.

Para Delors (1999:58):

Há que assumir a diversidade e o múltiplo pertencer como uma riqueza. A educação para o pluralismo é, não só, uma barreira contra a violência, mas um princípio ativo de enriquecimento cultural e cívico das sociedades contemporâneas. Entre o universalismo abstrato e redutor e o relativismo, para o qual nada mais existe para além do horizonte da cultura particular de cada um, há que afirmar ao mesmo tempo o direito à diferença, e a abertura ao universal.

De nada adianta adotar um programa de direitos humanos para a escola, se a própria escola não é democrática na sua relação de respeito aos alunos, pais, professores, funcionários e comunidade que a cerca. É nesse sentido que um programa de direitos humanos introduzido na escola serve, também, para questionar e enfrentar as suas próprias contradições e os conflitos vivenciados no seu cotidiano.

A educação para a tolerância e o respeito ao outro é condição necessária à democracia e deve ser considerada como uma tarefa geral e permanente. As práticas escolares devem valorizar o pluralismo cultural, apresentando-o como uma fonte de riqueza humana. Os preconceitos raciais, fatores de violência e de exclusão devem ser combatidos na prática democrática e cidadã da gestão escolar. Nesta escola, diferentes problemas são vivenciados no cotidiano, e as informantes apontam abaixo, os três mais importantes. 


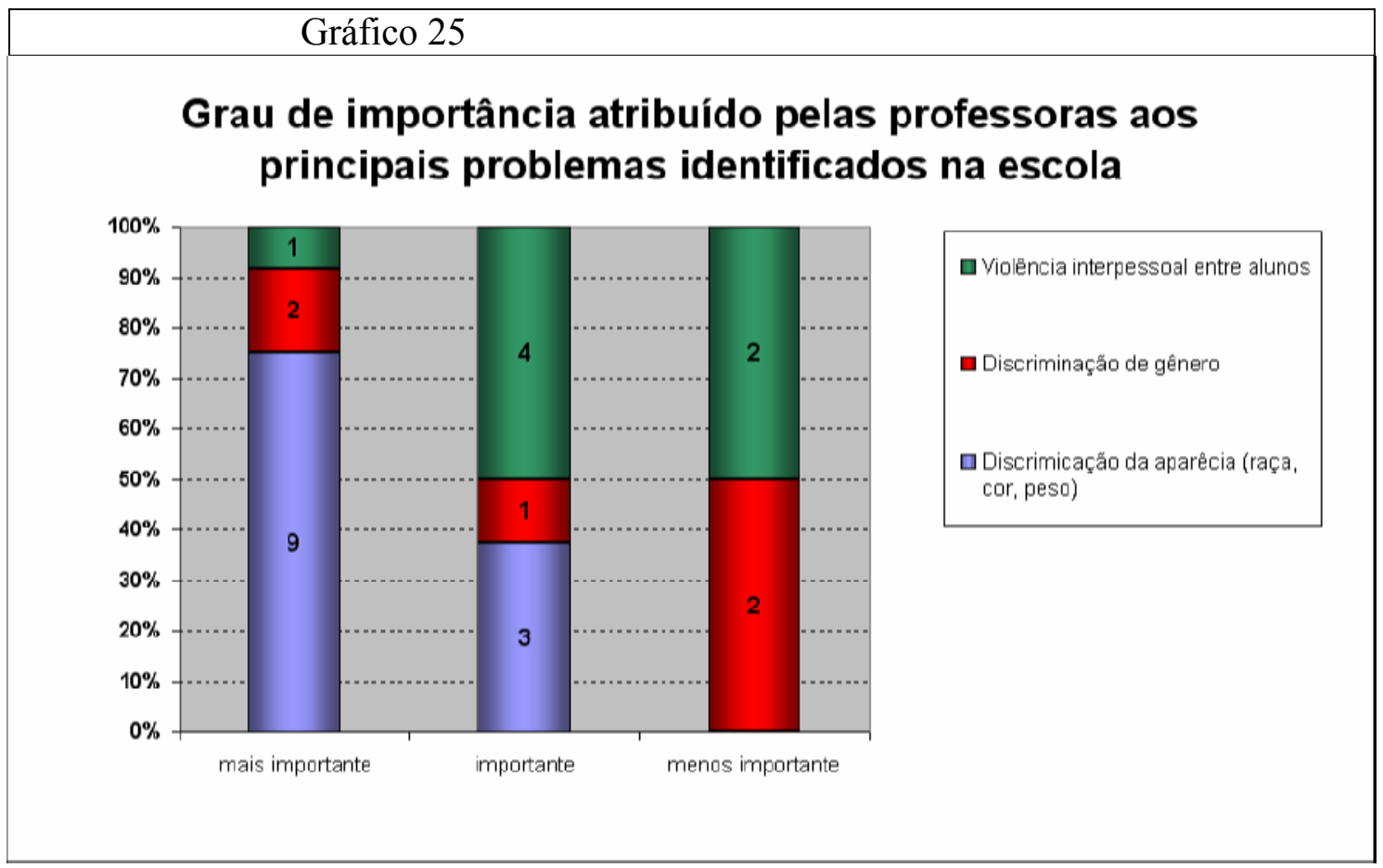

Dos problemas classificados como sendo mais importantes na escala, $75 \%$ destes são relacionados à discriminação da aparência, 20\% são relacionados à discriminação de gênero e $8 \%$ são devido à violência interpessoal.

Em relação ao fator classificado como sendo o segundo problema mais importante, $50 \%$ foi devido à violência interpessoal, $38 \%$ à discriminação da aparência e $12 \%$ à discriminação de gênero.

Para o problema classificado como sendo o terceiro mais importante, $50 \%$ foi devido à discriminação de gênero e os outros $50 \%$ estão relacionados à violência interpessoal entre os alunos.

De acordo com os problemas mencionados pelas professoras, a discriminação pela aparência prevalece sobre os demais, levando a supor a necessidade de cuidado com as atitudes dos alunos, especialmente aquelas vinculadas ao racismo. 


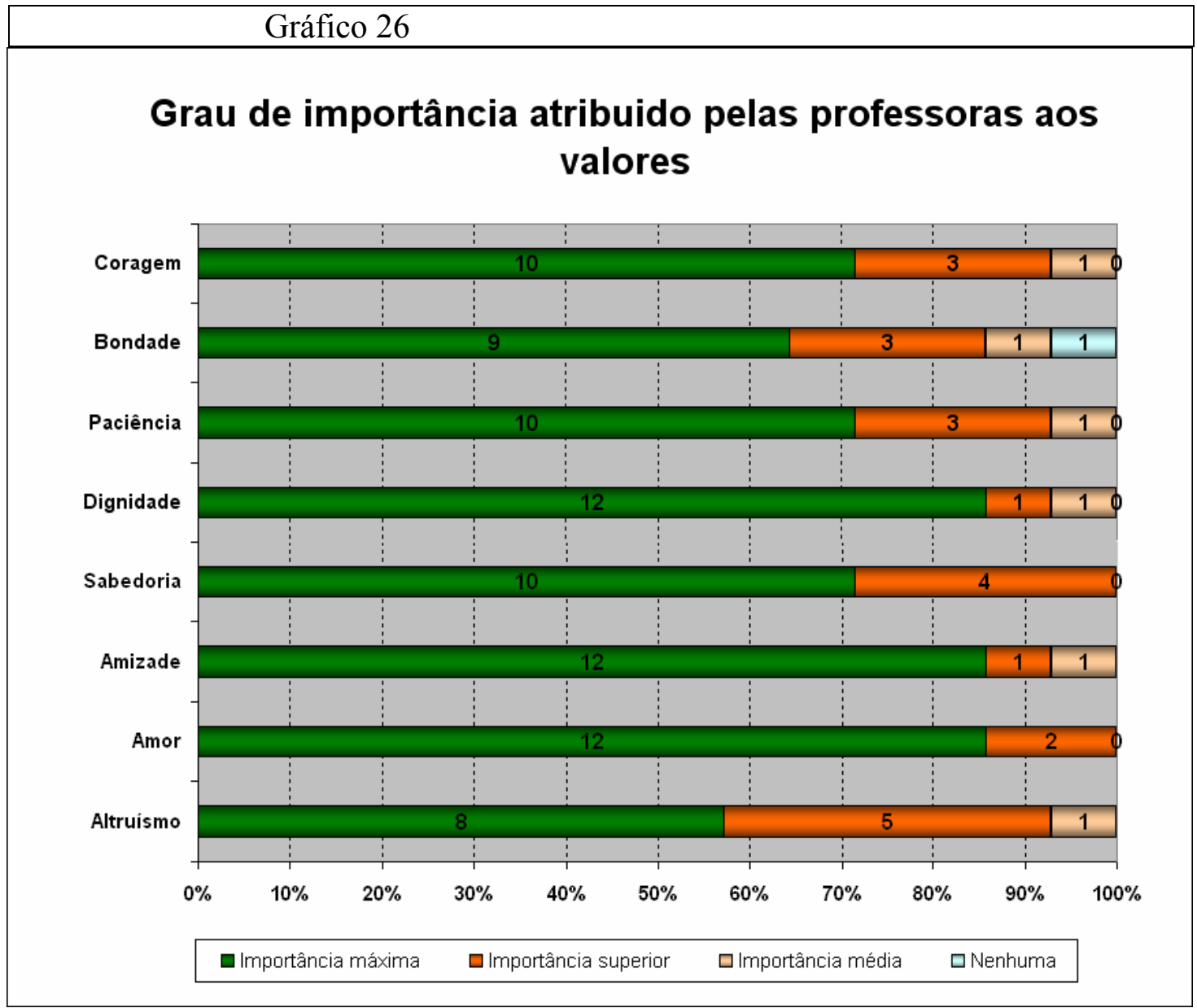

Outra questão relevante para análise refere-se aos valores que as docentes consideram significantes. Os valores mais apontados como importância máxima foram amor, amizade e dignidade (12 das 14 entrevistadas). Em seguida, são apontados os valores referentes à coragem, paciência e sabedoria (10); e finalmente, a bondade (9) e o altruísmo (8). Apenas 1 professora classificou a bondade como não tendo nenhuma importância.

De acordo com os valores mencionados pelos informantes, pode-se inferir que elas têm um quadro moral bastante adequado à função educativa. Neste sentido, elas individualmente parecem contribuir de modo satisfatório para a elaboração de um projeto político-pedagógico democrático e cidadão. 


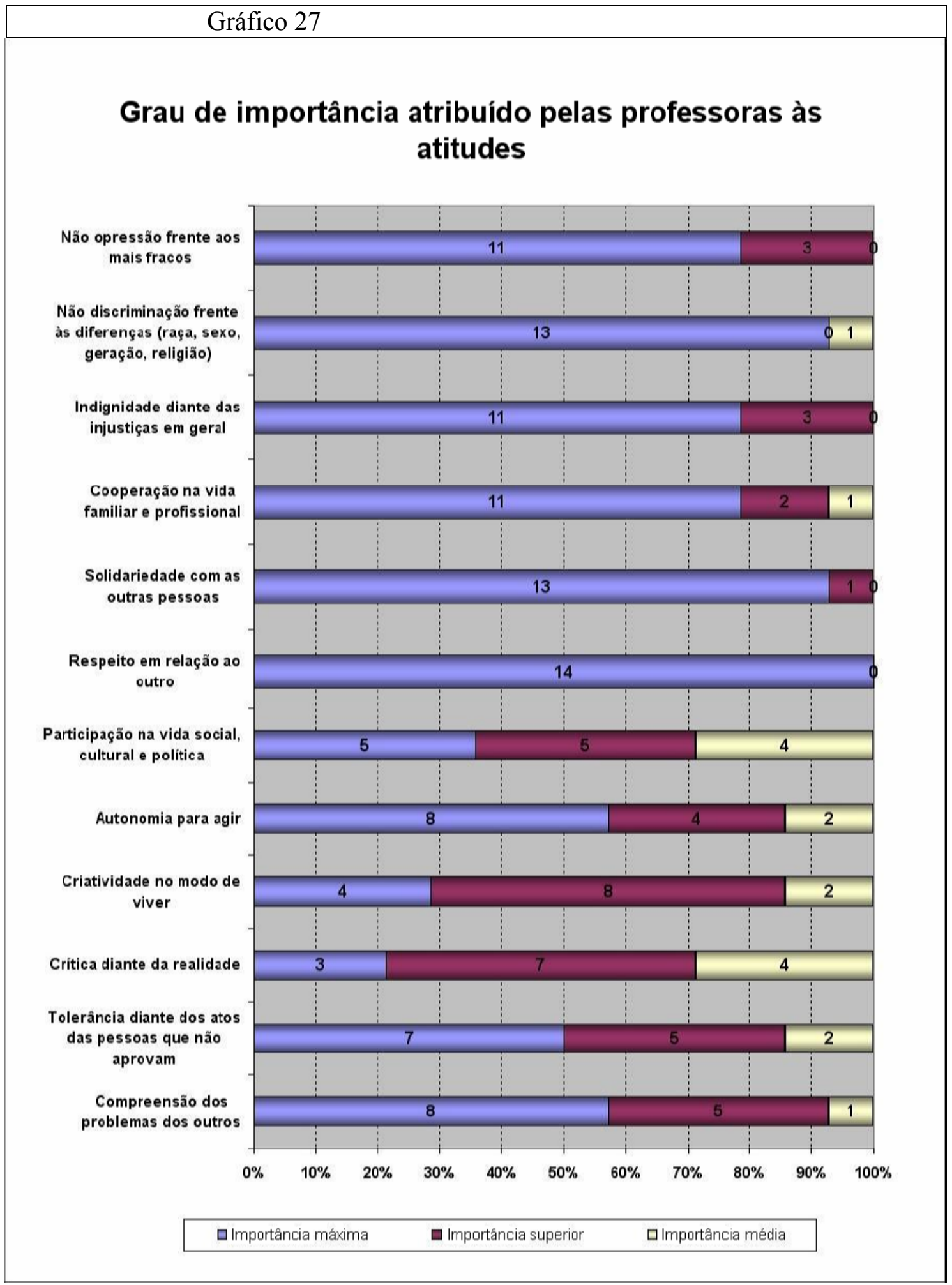

As atividades configuram um elemento fundamental para conhecer a postura das docentes no cotidiano da escola e na sala de aula. Os dados coletados revelam que em relação às atividades, a totalidade das professoras apontou o "respeito 
em relação ao outro" como tendo importância máxima na vida cotidiana. Em seguida, a "solidariedade com as outras pessoas" e a "não discriminação frente às diferenças (raça, sexo, geração e religião)" foram indicadas por 13 das 14 entrevistadas.

Cabe mencionar também que 11 informantes consideraram de importância máxima a "não opressão frente aos mais fracos", a "indignidade diante das injustiças em geral" e a "cooperação na vida familiar e profissional”. A "crítica diante da realidade" foi apontada como uma atitude de importância máxima por apenas 3 professoras.

Estes dados revelam que a maioria das docentes considera uma atitude essencial à prática educativa: o respeito ao outro. Além disso, as outras duas atitudes apontadas pelas 13 informantes demonstram que o corpo docente da escola está preocupado em diminuir as práticas discriminatórias e não solidárias existentes no cotidiano escolar.

No grupo focal com os alunos, foram citadas atitudes tais como : não agredir; não fazer brincadeiras que o outro não gosta; pensar antes de falar para não magoar o colega; não discriminar o outro independentemente da sua condição social, econômica ou de cor e pedir desculpas e reconhecer o erro.Este conjunto de atitudes expressa sintonia com a proposta de educação em direitos humanos feita no Plano Nacional de Educação em Direitos Humanos.

Os projetos da escola estão relacionados a questões referentes à diversidade, inclusão, respeito, valores e trabalho para a paz. As professoras vêem as diferenças entre os alunos novos, e os mais antigos. Trabalham valores, conversam, criam projetos, ensinam a não ficar retraído e a pedir ajuda a um adulto, levando em conta a conscientização e a sensibilização. Há uma orientadora na escola que toma medidas, estuda a criança e entra em contato com a família para solicitar parceria no acompanhamento escolar.

Para aprimorar a qualidade do trabalho pedagógico, torna-se necessário que a escola reformule seu tempo, estabelecendo períodos de estudo e 
reflexão com as equipes de educadores, fortalecendo a escola como instância da educação continuada.

Contudo, não se trata, apenas, da aquisição do espírito democrático. Trata-se, fundamentalmente, de ajudar o aluno a interpretar os fatos mais importantes relacionados com sua vida pessoal e coletiva.

Em relação à educação em direitos humanos e o projeto políticopedagógico da escola, todas as entrevistadas responderam que a escola está comprometida com a educação em direitos humanos, pois se preocupam em formar cidadãos críticos, que respeitem os valores do ser humano, finalidade social da escola colocada por elas. A finalidade cultural seria promover um maior conhecimento das culturas e trabalhar o respeito à diversidade; a finalidade política está relacionada à luta pelos direitos e à democracia; a finalidade profissional está centrada na formação continuada, na preparação para a vida, para que os alunos tenham um futuro melhor.

A estrutura pedagógica está apoiada nos seguintes serviços e procedimentos: sala de leitura, disponível para que a criança acompanhada pela professora faça consultas, leia livros literários e ainda assista a filmes educativos. $\mathrm{O}$ trabalho propõe o incentivo à leitura e estimula o contato da criança com os autores literários. O Laboratório de Informática Educativa conta com o recurso do computador e é utilizado como enriquecimento e dinamização das ações pedagógicas, oportunizando a todos o acesso à tecnologia. A Coordenação Pedagógica planeja, orienta, acompanha e avalia as atividades, dando suporte ao processo de ensino-aprendizagem e promovendo ações que contribuam com as práticas didático-pedagógicas. As professoras de apoio funcionam como reforço ao professor regente, no que se refere ao atendimento individualizado dos educandos, dentro e fora de sala de aula, além de realizar o acompanhamento dos planejamentos didáticos e atividades extraclasse, auxiliando no processo de adaptação curricular, contribuindo assim para o acesso e permanência da criança no espaço escolar. A orientação educacional tem caráter preventivo e envolve a comunidade educacional, promovendo a reflexão, aconselhando e valorizando o diálogo 
como instrumento da construção das relações humanas e do conhecimento.

A secretaria da escola é responsável pela escrituração escolar dos educandos, ex-educandos e professores. A portaria que acompanha o trânsito de pessoas na escola, especialmente as crianças, orienta as famílias para o cumprimento das regras da instituição quanto aos horários de entrada e saída dos turnos matutino e vespertino. A área de conservação e limpeza é responsável pela manutenção e higienização do prédio escolar. A merenda escolar é recebida do FNDE/MEC, contendo os gêneros básicos para a preparação do lanche escolar pelas merendeiras.

A direção garante o total funcionamento da escola, coordena as ações administrativas e pedagógicas, dentro dos princípios democráticos, oportuniza o trabalho coletivo com toda comunidade escolar. O Conselho Escolar e a APM são compostos por profissionais da escola e pais, além de representantes das crianças. Realizam um trabalho de parceria no apoio ao gerenciamento, buscando melhorias da área física, além de contribuir para as atividades pedagógicas e a integração de toda a comunidade. O Conselho Escolar e APM atuam nas discussões e deliberações do processo educativo.

Um dos entraves à efetivação do projeto político-pedagógico é a rotatividade do corpo docente, fato que nesta escola fica menos prejudicado. Além do problema da falta de professores, no início deste ano houve um desmonte da sala de apoio, de informática e a coordenadora pedagógica e um membro da direção teve que retornar à sala de aula. Suas funções ficaram um pouco defasadas em decorrência do acúmulo de trabalho. Tem também a questão da falta de um espaço coletivo para estudos e discussões periódicas entre os professores, que torna difícil operacionalizar a formação continuada dos docentes. Há um reduzido cronograma de reuniões previstos no calendário escolar que já vem pronto da Secretaria de Educação, impossibilitando remanejamentos e adaptações, sendo que muitas são usadas para discussão de questões administrativas.

Em relação ao funcionamento da estrutura pedagógica, prevalece uma 
relação harmoniosa, pois tudo é colocado para o coletivo, não de cima para baixo, mas por meio do diálogo, há um bom espaço para discussões que ocorre de maneira participativa. O aluno não é espectador, é ator, faz escolhas e age também.

A gestão dos recursos físicos e financeiros é coletiva e participativa, pois as verbas são discutidas, pelas professoras e pais em reuniões, além de bilhetes solicitando sugestões para melhorias. Foi elaborando uma lista de prioridades que os pais, professores, crianças e comunidade definiram a estrutura atual da escola que é muito boa em relação às outras. Foi feito tudo na ordem que as pessoas consideravam mais importante: televisão, dvd, vídeoke, máquina digital, "scanner", computador, vídeo-cassete, data-show e impressoras. Tem computador nas salas dos servidores, no laboratório de informática e nas salas dos professores, além de jogos pedagógicos e quadro branco.

A avaliação é de caráter diagnóstico, formativo, processual e crítico. Cada professora tem a liberdade de avaliar como quiser, mas todas respeitam essas diretrizes e preferem fazer uma avaliação cotidiana. A maioria considera ter uma visão mais progressista de mundo.

Em relação à avaliação do projeto político-pedagógico, este é considerado importante, uma vez que é a oportunidade para verificar acertos e erros e definir as mudanças necessárias e curto e médio prazo. Nesse sentido, os dados coletados nessa pesquisa parecem indicar que a educação em direitos humanos foi contemplada no projeto político-pedagógico adotado pela escola. 


\section{CONCLUSÃO}

Os aspectos levantados não constituem conclusões definitivas nem se esgotam por si mesmos. São pontos de reflexão que se colocam no caminho da democratização da escola pública visando uma atuação mais comprometida com a realidade social, permitindo que os educandos se tornem sujeitos críticos e ativos em seu processo de aprendizagem. O ritmo e a forma dessa caminhada vai depender do contexto da sociedade, da política educacional do DF e de cada escola em particular.

Essa articulação entre a universidade e as instituições de Ensino Fundamental, ao mesmo tempo em que oferece à universidade por meio dessa pesquisa a oportunidade de analisar práticas concretas e teorizar sobre elas, fornece à escola subsídios para a organização do trabalho pedagógico, induzindo-a a avançar na proposta e na consolidação dessa parceria.

Em relação à hipótese a respeito do projeto político-pedagógico desta escola pública de educação básica não refletir as condições necessárias para a formação dos alunos na área de educação em direitos humanos, ela foi refutada, uma vez que os dados colhidos na pesquisa de campo mostram que embora a realidade da escola pública seja ainda bastante complexa, parece possível ver a autonomia emergir do interior das próprias escolas por meio de um projeto político-pedagógico assumido por todos, o qual assegure autenticidade a novas propostas. Este foi o caso da Escola Classe 304 Norte, onde a presença de uma gestão democrática voltada para a participação da comunidade escolar permitiu a definição de práticas pedagógicas cidadãs. Desse modo, esta escola garante a existência de um projeto político-pedagógico pautado na educação em direitos humanos e voltado para formação de uma cultura de respeito à dignidade humana através da promoção e da vivência dos valores da liberdade, da justiça, da igualdade, da solidariedade, da cooperação, da tolerância e da paz. 


\section{REFERÊNCIAS BIBLIOGRÁFICAS}

AFONSO, Maria Rosa. Educação em Direitos Humanos: aspectos da realidade portuguesa. Jornal da Rede Estadual de Direitos Humanos do Rio Grande do Norte. Edição Especial EDH - 2006, p.05.

AGENDA ESCOLAR DA ESCOLA CLASSE 304 NORTE. Brasília, 2006.

ALVAREZ, Benjamín. “Autonomía Escolar y reforma Educativa”. In: PREAL. Creando autonomía en las escuelas. Santiago: PREAL/LOM Ediciones, 2002, p. 09-39.

BENEVIDES, Maria Victoria. Palestra de abertura do Seminário de Educação em Direitos Humanos. São Paulo, 18/02/2000. p. 01.

BOAS, Benigna Maria de F. V. O projeto político-pedagógico e a avaliação. In: VEIGA, Ilma Passos e REZENDE, Lúcia M. G. Escola: espaço do projeto político pedagógico. Papirus Editora, Campinas/SP, 8 edição, 2005.

BRESSAN, Flávio. O método de estudo de caso. Disponível em http:

//www.fecap.br/adm_online/art11/flavio.htm. Acesso em 02.jun.07

BUSSMANN, Antônia C. O projeto político-pedagógico e a gestão da escola. In: VEIGA, Ilma Passos (Org.). Projeto Político e pedagógico da escola: uma construção possível. Papirus Editora, Campinas/SP, 14 edição, 2004.

CANDAU, Vera M. Educação em Direitos Humanos no Brasil: realidades e perspectivas. In: CANDAU, V. M. e SACAVINO, S. Educar em Direitos Humanos: construir democracia. Rio de Janeiro, DP\& ${ }^{\mathrm{a}}$ Ed. 2000.

CAVAGNARI, Luzia Borsato. Projeto político-pedagógico, autonomia e realidade escolar: entraves e contribuições. In: VEIGA, Ilma Passos e REZENDE, Lúcia M. G. Escola: espaço do projeto político pedagógico. Papirus Editora, Campinas/SP, 8 a edição, 2005.

CANDAU, Vera Maria. Educação em Direitos Humanos hoje. Jornal da Rede Estadual de Direitos Humanos do Rio Grande do Norte. Edição Especial EDH 2006, p.02.

DECLARAÇÃO DOS DIREITOS DO HOMEM E DO CIDADÃO 26/08/1789. In: BRANDÃO, Adelino (Org.). Os direitos humanos - antologia de textos históricos. São Paulo: Landy Livraria Editora e Distribuidora LTDA, 2001.

DELORS, Jacques. Educação: um tesouro a descobrir. São Paulo: Cortez, 3ª ed., 1999.

DEMO, Pedro. Política social e política educacional. Educação, cultura e política 
social. Porto Alegre - RS: Editora Feplam, 1979.

1995.

Educação e qualidade. Campinas: Papirus Editora, $2^{\text {a }}$ edição,

. Pesquisa e informação qualitativa: aportes metodológicos.

Campinas: Papirus Editora, 2001.

DESLANDES, Suely Ferreira. Pesquisa social: teoria método e criatividade / Suely Ferreira Deslandes, Otávio Cruz Neto, Romeu Gomes; Maria Cecília de Souza Minayo (organizadora). - Petrópolis, RJ: Vozes, 1994.

FALKEMBACH, Elza Maria Fonseca. Planejamento participativo: uma maneira de pensá-lo e encaminhá-lo com base na escola. In: VEIGA, Ilma Passos A. (org). Projeto político-pedagógico da escola: uma construção possível. Papirus Editora, Campinas - São Paulo. 17 edição, 2004.

FLICK, Uwe. Uma introdução à pesquisa qualitativa. Trad. Sandra Netz. 2 ed. Porto Alegre: Bookman, 2004.

FREIRE, Paulo. Pedagogia do Oprimido. 17ª ed. Rio de Janeiro: Paz e Terra, 1970.

GARCIA, Bianco Z. "Projeto político-pedagógico, autonomia e gestão democrática da escola: uma perspectiva harbemasiana". In: TORRES, Carlos A. (comp.). Paulo Freire y la Agenda de la Educación Latinoamericana en el Siglo XXI. Buenos Aires: Clacso, Primera Edición, 2001, p. 267-294.

GATTI, Bernardete Angelina. Grupo focal na pesquisa em ciências sociais e humanas. Brasília: Líber Livro Editora, 2005.

HORTA, Maria Del Mar Rubio. Educar em direitos humanos: compromisso com a vida. In: CANDAU, V. M. e SACAVINO, S. Educar em direitos humanos: construir democracia. Rio de Janeiro, DP\&A Ed., 2000.

JOHANNPETER, Jorge Gerdau. Todos pela educação. Artigo disponível em $<$ http://www.reescrevendoaeducacao.com.br/2006 $>$. Acesso em 05.jun.07

LIMA, Antônio Bosco de (UNIOESTE) e VIRIATO, Edaguimar Orquizas (UNIOESTE). “As políticas de descentralização, participação e autonomia: Desestatizando a educação pública". Disponível em $<$ http://www.anped.org.br/reunioes/23/textos/0523t.PDF> . Acesso em 05.jun.07.

MAGENDZO K., Abraham. Educación em derechos humanos: un desafío para los derechos de hoy. Ensayo 2006. Santiago: LOM Ediciones, $1^{a}$ ed., 2006.

MARCONI, Marina de Andrade e LAKATOS, Eva Maria. Técnicas de pesquisa: planejamento e execução de pesquisa, amostragens e técnicas de pesquisas, 


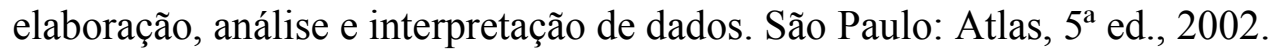

MARQUES, Mário O. Escola, aprendizagem e docência: imaginário social e intencionalidade política. In: VEIGA, Ilma Passos A. (org). Projeto políticopedagógico da escola: uma construção possível. Papirus Editora, Campinas São Paulo. $17^{a}$ edição, 2004.

MELLO, Guiomar Namo de. "Proposta Pedagógica e autonomia da escola".In: PREAL. Creando autonomía en las escuelas. Santiago: PREAL/LOM Ediciones, 2002, p. $78-85$.

NEVES, Carmen Moreira de Castro. Autonomia da escola pública. In: VEIGA, Ilma Passos A. (org). Projeto político-pedagógico da escola: uma construção possível. Papirus Editora, Campinas - São Paulo. 17ª edição, 2004.

PLANO NACIONAL DE EDUCAÇÃO EM DIREITOS HUMANOS. Edição 2006 Versão preliminar. Ministério da Educação.

RETRATO PEDAGÓGICO DA ESCOLA CLASSE 304 NORTE. Brasília, 2007.

SANTIAGO, Anna Rosa F. Projeto político-pedagógico da escola: desafio à organização dos educadores. In: VEIGA, Ilma Passos A. (org). Projeto políticopedagógico da escola: uma construção possível. Papirus Editora, Campinas São Paulo. $17^{\mathrm{a}}$ edição, 2004.

SANTIAGO, Anna Rosa F. e ZASSO, Silvana Maria B. Projeto político-pedagógico: a experiência de uma escola de periferia urbana na construção de sua identidade. In: VEIGA, Ilma Passos A. (org). Projeto político-pedagógico da escola: uma construção possível. Papirus Editora, Campinas - São Paulo. 17 edição, 2004.

TOSI, Giuseppe (Org.). Direitos humanos: História, teoria e prática. João Pessoa: Editora Universitária/UFPB, 2005.

VEIGA, Ilma P. A. Educação Básica e Educação Superior: projeto políticopedagógico. Campinas - São Paulo: Papirus, 2004, capítulos 01 e 02.

VEIGA, Zilah de Passos Alencastro. As instâncias colegiadas da escola. In: VEIGA, Ilma P. A. e RESENDE, Lúcia M. G. Escola: espaço do projeto políticopedagógico. Papirus Editora, Campinas - São Paulo. 8a edição, 2005.

VEIGA, Ilma Passos Alencastro. Educação Básica: projeto político-pedagógico. Papirus Editora, Campinas - São Paulo. $8^{\mathrm{a}}$ edição, 2005.

WARAT, Luis Alberto. Direitos Humanos: Subjetividade e práticas pedagógicas. In: Universidade de Brasília. Educando para os Direitos Humanos: Pautas Pedagógicas para a Cidadania na Universidade. Brasília. Editora Síntese. 2003. p. 57-60. 
YIN, Robert K. Case Study Research: design and methods. Tradução e síntese de Ricardo Lopes Pinto. Adaptação de Gilberto de Andrade Martins. Acesso em 10 jun. 07. Disponível em http: //www.focca.com.br/cac/textocac/Estudo_Caso.htm. 


\section{ANEXO}

\section{ROTEIRO DO GRUPO FOCAL COM PAIS DOS ALUNOS DA $1^{\mathrm{a}}$ a $4^{\mathrm{a}}$. SÉRIES}

\section{DA ESCOLA CLASSE DA 304 NORTE}

\section{QUESTÕES}

1) Quais os principais problemas deste Centro de Ensino?

(Tem violência na escola? Por que? Que tipo?Como a escola enfrenta isso?

Tem discriminação de raça ou sexo?Por que?Como a escola lida com isso?

Tem discriminação social e/ou econômica?

Tem uso de drogas na escola? Por que?O que a escola faz diante disso?

Que outros problemas têm a escola?)

2) Os pais participam das atividades deste Centro de Ensino? Por que?

Se sim: Como?

(Os pais participam das reuniões da escola? Por que)?

Os pais participam do Conselho Escolar?Por que?

Os pais participam da Associação de Pais e Mestre?Por que?

Que importância tem participar da vida da escola?)

3)O sr (a) conhece seus direitos? Quais são?

(Estudar é um direito? Por que)?

Ter saúde é um direito? Por que?

Ter casa e comida é um direito? Por que?

Ter roupa para vestir é um direito? Por que?

Que outros direitos os senhores tem?)

4)Qual a opinião do sr (a) sobre o ensino (programa das disciplinas, recursos didático- 
pedagógicos, infra-estrutura da escola, relação com os professores) dado para seu (sua) filho (a) nesta escola?(Pontos positivos e negativos)

5) $\mathrm{O}$ que este Centro de Ensino faz para garantir uma vida digna para seu (sua) filho(a)?

6) Atitudes

Que importância tem respeitar os outros e ser respeitado?Dê exemplos.

A solidariedade com outras pessoas é importante? Por que?

O que é mais importante para viver feliz?

ROTEIRO DO GRUPO FOCAL COM OS ALUNOS DA $1^{\mathrm{a}}$ a $4^{\mathrm{a}}$. SÉRIES DA ESCOLA CLASSE DA 304 NORTE

\section{QUESTÕES}

1. Quais os principais problemas deste Centro de Ensino?

(Tem violência na escola? Por que?

Tem violência entre os alunos?Por que?

Tem violência no relacionamento entre alunos e professores?Por que?

Tem rivalidade entre grupos na escola? Quais? Por que?

A polícia já veio aqui? Por que? O que acham disso?

Na escola tem discriminação de sexo ou raça?Por que?

$\mathrm{Na}$ escola tem problema de droga? Por que?

O que a vizinhança acha da escola?)

2. Vocês têm direitos? Quais?Por que?Dê exemplos dos direitos que vocês tem.

(Estudar é um direito? Por que)?

Ter saúde é direito?Por que?

Ter casa e comida é direito? Por que?

Ter roupa para vestir é direito?Por que?

Que outros direitos vocês têm? 
3. Os alunos participam das atividades da escola? Por que?

(A escola tem grêmio estudantil? Por que? O que faz o grêmio)?

Vocês participam de alguma decisão da escola? Por que?

Que importância tem participar das decisões tomadas pela escola?)

4. Qual a opinião de vocês sobre o ensino (programa das disciplinas, recursos didático-pedagógicos e materiais, infra-estrutura da escola, relação com os professores em sala de aula) desta escola?(Pontos positivos e negativos)

5. O que este Centro de Ensino deveria fazer para garantir um futuro com uma vida digna para vocês?

6. Atitudes

Vocês respeitam os outros e são respeitados na escola ? Dê exemplos.

A solidariedade com outras pessoas é importante? Por que?

O que é mais importante para viver feliz?

$\begin{array}{llllll}\text { ROTEIRO } & \text { DE } & \text { ENTREVISTA } & \text { COM } & \text { PROFESSORES, DIRETORES, }\end{array}$ COORDENADOR PEDAGÓGICO E ORIENTADOR PEDAGÓGICO DA ESCOLA CLASSE 304 NORTE DE BRASÍLIA. 